\title{
Türkiye'de 2007-2017 Yılları Arasında Spor Branşları ve Cinsiyete Göre Sporcu Sayılarının Dağılımı
}

\author{
Gözde ERSÖZ* $\quad$ Bayram ALAGÖZ**
}

\section{Özet}

Bu çalışmanın amacı, 2007-2017 yılları arasındaki on yıllık periyod içerisinde Türkiye' deki sporcu sayılarına ilişkin bilgilerini spor dalı ile cinsiyete göre dağılımına ilişkin değişikliği ortaya koymaktır. Araştırma tarama modelinde betimsel bir araştırmadır. Araştırmanın verileri Türkiye Spor Bakanlığına bağlı olan Gençlik Hizmetleri Genel Müdürlüğü'nin web sitesinde yer alan arşiv dokümanlarından yararlanılarak elde edilmiştir. Verilerin analizinde betimsel istatistik yöntemlerinden frekans analizi kullanılmıştır. Çalışmanın sonucunda tüm spor branşlarında sporcu sayılarının yeterli düzeylere ulaşmadığı, spor branşlarında yıllara göre tutarlı olmayan artış ve azalmalar olduğu ve kadın sporcu sayılarının erkeklere göre düşük düzeyde olduğunu ortaya koyulmuştur.

Anahtar Kelimeler: Sporcu lisansı, Gençlik ve Spor, İstatistik

\section{Distribution of Athletes Between 2007-2017 According to Sport Branches and Gender in Turkey}

\begin{abstract}
The aim of this study is to reveal the changes in the distribution of athletes according to the branch of sports and gender within ten years from 2007 to 2017 years in Turkey. The descriptive research model was used in this study. Research data were taken from General Directorate of Youth Services (GHGM)' s website as statistical archive document. In the analysis of the data, frequency analysis which is one of the descriptive statistical methods, was used. As a result of the study, it was revealed that the number of athletes did not reach sufficient levels in all sports branches, there were inconsistent increases and decreases in sports branches over the years, and the number of female athletes was lower than men.
\end{abstract}

Keywords: Sportsman license, Youth and Sports, Statistics

\section{GíRIş}

Ülkemizde bireylerin hangi spor yıllarda spor branşlarına katılımın arttı̆̆ branşlarını daha çok seçtikleri, hangi hangi yıllarda azaldığı, spor yapan

\footnotetext{
* Doç. Dr. Namik Kemal Üniversitesi, Beden Eğitimi ve Spor Yüksekokulu, Tekirdağ/Türkiye, gozde0007@ gmail.com

** Namik Kemal Üniversitesi, Beden Eğitimi ve Spor Yüksekokulu, Tekirdağ/Türkiye
} 
bireyler arasında cinsiyet dağılımının analizi spor ortamlarında çalışan antrenörler ve spor yöneticileri için önemli bir veridir. Spora katılımın arttırılması, hem fiziksel, psikolojik ve sosyal açıdan faydalı olan fiziksel aktivitenin arttırılması, hem de ülkemizdeki sportif başarının arttırılması açısında çok önemlidir (Smoll ve Smith, 2002). Spora katılımın arttırılmasında mevcut katılımcıların analizinin yapılması da bu alanda çalışanların planlama yapmasında katkı sağlar. Alanyazın incelendiğinde Türkiye' deki Gençlik Hizmetleri Genel Müdürlüğü (GHGM)' nün arşivindeki lisanslı sporcu verilerinin betimsel analizi yapılmamıştır.

Ülkemizde kamuda Federasyonlar düzeyinde spor yönetimi sürecinde bazı spor branşlarının örgütlenmesi senelerce aynı kalırken, bazıları isim değiştirmiş bazılarının ise federasyonu tamamen iptal edilmiştir. Türkiye'de Federasyon yapıları incelendiğinde; 2007 yılında toplam 55 spor branşında Federasyon faaliyet göstermiştir. $\mathrm{Bu}$ sayı 2008 yılında da sabitliğini korumuştur. 2009 yılında 4 tane spor dalı (Gelişmekte olan Spor Bransşları Federasyonu., Hava Sporları, Hokey ve Özel Sporcular) eklenerek toplam Federasyon sayısı 59 olmasına rağmen, çıkarılan spor branşları (Üniversite sporları, çim hokeyi ve zihinsel engelliler) nedeniyle sayı 56'ya düşmüştür. 2010 yılında 1 branş (Kızak) eklenerek sayı 57'ye çıkmıştır. Bu sayı, 2011 yılında da yerini spor branşlarından 'Beyzbol ve Softbol" çıkartılıp, yerine "Ragbi", eklenmesiyle korumuştur. 2012 yılında 1 branş (Dijital Oyunlar Federasyonu) eklenerek toplam sayı 58 olsa da, 2013’te 2 branş (Dijital oyunlar ve Hava sporları) çıkartılarak toplam spor branşları 56' ya düşmüştür. 2014 ve 2015 yılında spor branşlarının toplamı 56 iken, 2016 yılında 'Curling', branşı eklenerek toplam sayı 57 ulaşmıştır. Son olarak 2013 yılında çıkarılan hava sporları branşı, tekrar 2017 yılında eklenerek spor branşlarının toplam sayıları $\quad 58$ 'e ulaşmıştır (https://sgm.gsb.gov.tr/Sayfalar/175/105/I statistikler Erişim tarihi: 18 Eylül 2018).

Bu çalışmada 2007-2017 yılları arasındaki GHGM' ne kayıt edilen sporcu lisans sayılarına ilişkin gelişiminin incelenmesi, branş ve cinsiyet yönünde lisanslı sporcu sayılarının dağılımlarının ortaya konması amaçlanmıştır.

\section{YÖNTEM Araştırma Modeli}

Araştırma tarama modelinde betimsel bir araştırmadır. Tarama modelleri, geçmişte ya da halen var olan bir durumu var olduğu şekliyle betimlemeyi amaçlayan 
Ersöz, G., Alagöz, B. / Türkiye’de 2007-2017 Yılları Arasında Spor Branşları ve Cinsiyete Göre Sporcu Sayılarının Dağılımı

yaklaşımlardır (Karasar, 2003). Araştırmada doküman incelemesiyle toplanan Spor Hizmetleri Genel Müdürlüğü (GHGM)'nün yıllara göre sunmuş olduğu veriler, Excel (2013) paket programında düzenlenmiş ve grafiksel sunumu gene aynı bilgisayar programında yapılmıştır.

\section{Araştırmanın Sinırlılıkları ve Kapsamı}

Araştırma GHGM' nin 2007-2017 y1lları arasında lisanslı ve faal (kadın, erkek ve toplam sayılar) sporcuların toplam sayıları baz alınarak gerçekleşmiştir. Araştırma sırasında verilerin orijinelliğiyle oynanılmamış, reel olarak kullanılmıştır.

\section{Evren ve Örneklem}

Bu çalışmanın evreni Türkiye'de 2007 ile 2017 yılları arasında bulunan tüm sporcuların, çalışmanın örneklemi GHGM' nin kayıt altına aldığı spor dalları ve lisanslı sporculardan oluşmaktadır.

\section{Verilerin Toplanmast}

Araştırmanın verileri, lisanslı ve faal sporcuların istatistiklerini yayınlayan Spor Genel Müdürlüğünün Gençlik ve Spor Bakanlığı uzantılı http://sgm.gsb.gov.tr internet sitesinden alınan verilerin sıralaması 2007 yılına göre düzenlenmiştir, eklenen spor branşları ise yıllara göre listenin sonuna eklenmiştir. Bazı spor branşlarında verilerde tutarsızlıklar görülmüş ve o yıllara ait bilgiler değerlendirmeye alınmamıştır.

\section{Verilerin Analizi}

Araştırmanın kapsamını oluşturan 20072017 y1lları arası lisanslı ve faal sporcu sayıları üzerinde içerik analizleri yapılmıştır. İçerik analizi; nicel veriler sistemli bir şekilde analiz edilerek, yıllara göre değişiklik gösterilen veriler, yazılı olarak ifade edilmiştir.

\section{BULGULAR}

Tablo 1: Atıcılık Spor Dalında Yıllara Göre Lisanslı Sporcu Sayıları

\begin{tabular}{cccc}
\hline \multicolumn{4}{c}{ LISANSLI SPORCU SAYISI } \\
Yıllar & Kadın & Erkek & Toplam \\
\hline 2008 & 88 & 428 & 516 \\
2009 & 87 & 543 & 630 \\
2010 & 85 & 1185 & 1270 \\
2011 & 247 & 1277 & 1524 \\
2012 & 216 & 1213 & 1429 \\
2013 & 233 & 1000 & 1233 \\
2014 & 189 & 925 & 1114 \\
2015 & 308 & 403 & 711 \\
2016 & 110 & 64 & 174 \\
2017 & 423 & 1302 & 1725 \\
\hline
\end{tabular}

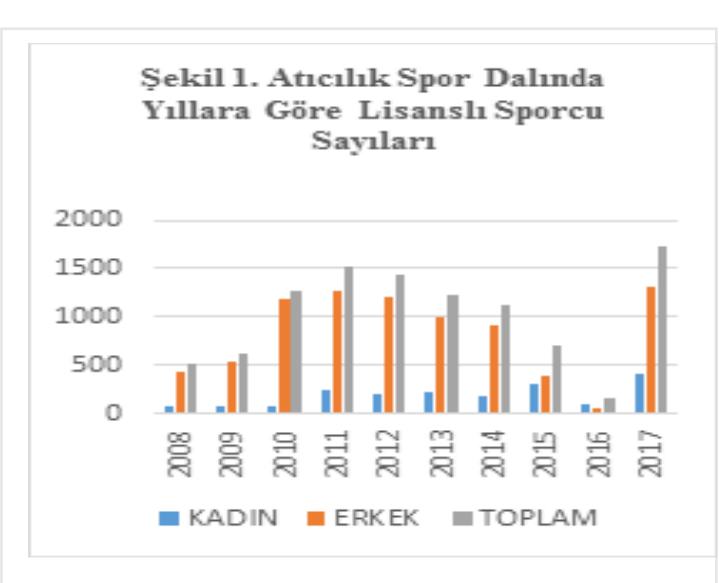


Atıcılık spor dalında 2007 yılına kadar toplam 1788 kadın, 12875 erkek toplam 14663 sporcunun kayıtlı olduğu görülmektedir. Kadınlarda lisanslı sporcu sayısı en düşük 2010 yılında, erkeklerde ise 2016 y1lında görülmüştür. En yüksek sporcu kaydina ise kadinlarda ve erkeklerde 2017 yılından ulaşılmıştır.

Tablo 2: Atletizm Spor Dalında Yillara Göre Lisanslı Sporcu Sayıları

\begin{tabular}{cccc}
\hline \multicolumn{4}{c}{ LISANSLI SPORCU SAYISI } \\
Yıllar & Kadın & Erkek & Toplam \\
\hline 2010 & 2796 & 4946 & 7742 \\
2011 & 2283 & 4329 & 6612 \\
2012 & 4590 & 7795 & 12385 \\
2013 & 7614 & 12329 & 19943 \\
2014 & 5258 & 8406 & 13664 \\
2015 & 5938 & 6194 & 12132 \\
2016 & 4701 & 4892 & 9593 \\
2017 & 6733 & 11328 & 18061 \\
\hline
\end{tabular}

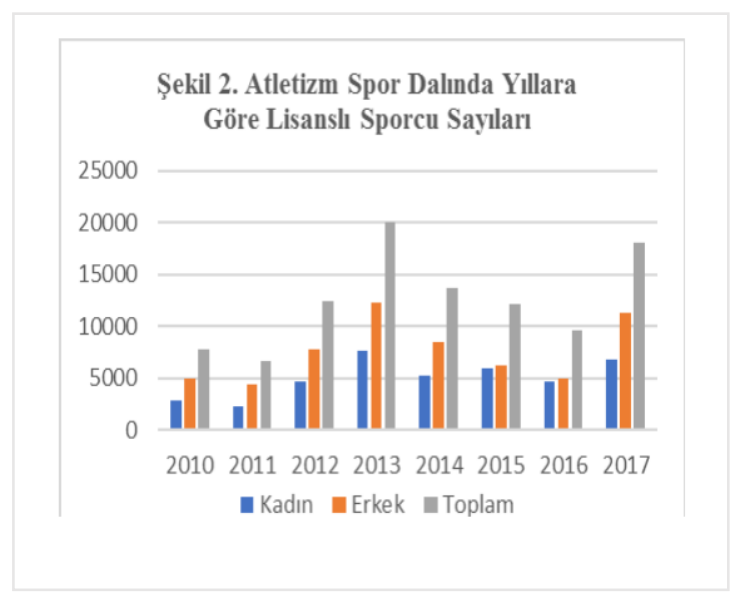

Atletizm branşında 2007 yılına kadar 36077 kadın, 66911 erkek toplam 102988 sporcu kayıtlı görülmektedir. Kadınlarda ve erkeklerde lisansli sporcu sayısı en düşük 2011 y1lında görülmüşsür. En yüksek sporcu kaydına ise kadınlarda ve erkeklerde 2017 yılından ulaşılmıştır. 2008 yılındaki veriler tutarsız olduğu için değerlendirmeye alınmamış 2010 yılında itibaren yer alan bilgiler tabloya eklenmiştir.

Tablo 3: Badminton Spor Dalında Yıllara Göre Lisanslı Sporcu Sayıları

\begin{tabular}{cccc}
\hline \multicolumn{4}{c}{ LISANSLI SPORCU SAYISI } \\
Yıllar & Kadın & Erkek & Toplam \\
\hline 2008 & 920 & 1381 & 2301 \\
2009 & 690 & 997 & 1687 \\
2010 & 1284 & 1648 & 2932 \\
2011 & 1803 & 2157 & 3960 \\
2012 & 2591 & 3217 & 5808 \\
2013 & 4687 & 5491 & 10178 \\
2014 & 3128 & 3856 & 6984 \\
2015 & 3712 & 3445 & 7157 \\
2016 & 3712 & 3409 & 7121 \\
2017 & 5285 & 7307 & 12592 \\
\hline
\end{tabular}

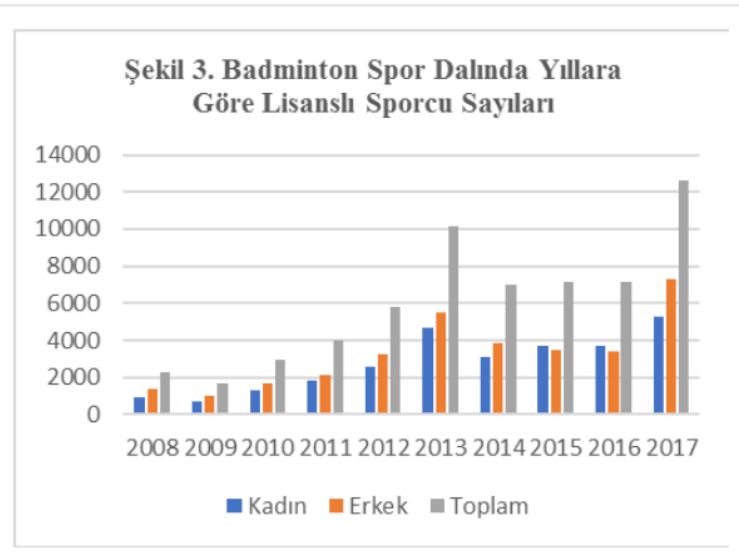

Badminton branşında 2007 yılına kadar 9165 kadın, 14876 erkek toplam 24041 sporcu kayıtlı görülmektedir. Bu branşta 
Ersöz, G., Alagöz, B. / Türkiye’de 2007-2017 Yılları Arasında Spor Branşları ve Cinsiyete Göre Sporcu Sayılarının Dağılımı

en az sporcu lisansı 2009 yılında lisanslı sporcu sayısı en düşük 2008 çıkarılmıştır. 2010, 2011 ve 2012 yılında, erkeklerde ise 2016 yılında yıllarında sporcu lisansı sayıları doğrusal düzeyde artmış, 2013 yılında en yüksek düzeye ulaşıp, 2014, 2015 ve 2016 yıllarında tekrar daha düşük düzeyde gerilemiş ve 2017 yılında tekrar yüksek düzeye ulaşmıştır.

Tablo 4: Bedensel Engelliler Spor Dalında Y1llara Göre Lisanslı Sporcu Sayıları

\begin{tabular}{cccc}
\hline \multicolumn{4}{c}{ LiSANSLI SPORCU SAYILARI } \\
Yıllar & Kadın & Erkek & Toplam \\
\hline 2008 & 57 & 392 & 449 \\
2009 & 63 & 320 & 383 \\
2010 & 81 & 331 & 412 \\
2011 & 62 & 323 & 385 \\
2012 & 65 & 342 & 407 \\
2013 & 95 & 468 & 563 \\
2014 & 118 & 496 & 614 \\
2015 & 121 & 443 & 564 \\
2016 & 64 & 247 & 311 \\
2017 & 118 & 467 & 585 \\
\hline
\end{tabular}

Tablo 5: Bisiklet Spor Dalında Yıllara Göre Lisanslı Sporcu Sayıları

\begin{tabular}{cccc}
\hline \multicolumn{4}{c}{ LíSANSLI SPORCU SAYISI } \\
Yıllar & Kadın & Erkek & Toplam \\
\hline 2008 & 29 & 662 & 691 \\
2009 & 46 & 634 & 680 \\
2010 & 126 & 763 & 889 \\
2011 & 119 & 1143 & 1262 \\
2012 & 226 & 1248 & 1474 \\
2013 & 820 & 2213 & 3033 \\
2014 & 660 & 2148 & 2808 \\
2015 & 546 & 1861 & 2407 \\
2016 & 482 & 1733 & 2215 \\
2017 & 602 & 3382 & 3984 \\
\hline
\end{tabular}

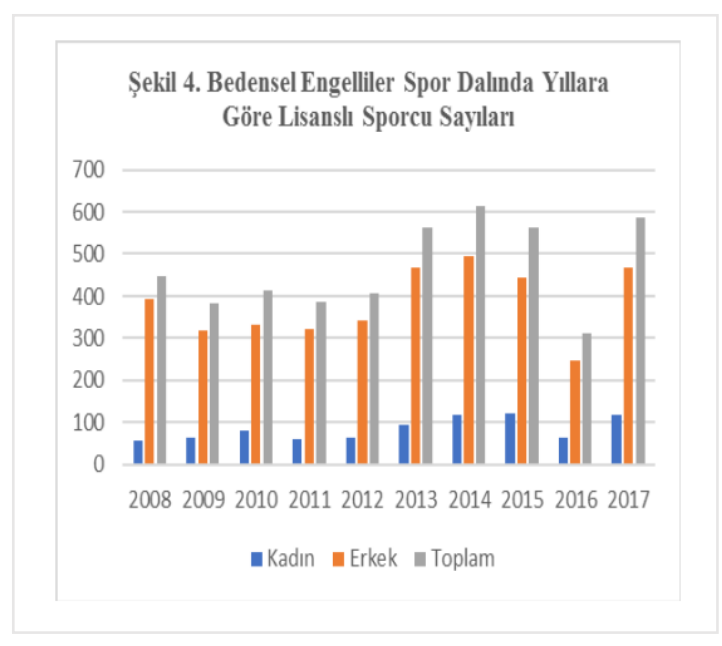

Bedensel Engelliler branşında 2007 yılına kadar 216 kadın, 1708 erkek toplam 1924 sporcu kayıtlı görülmektedir.Kadınlarda

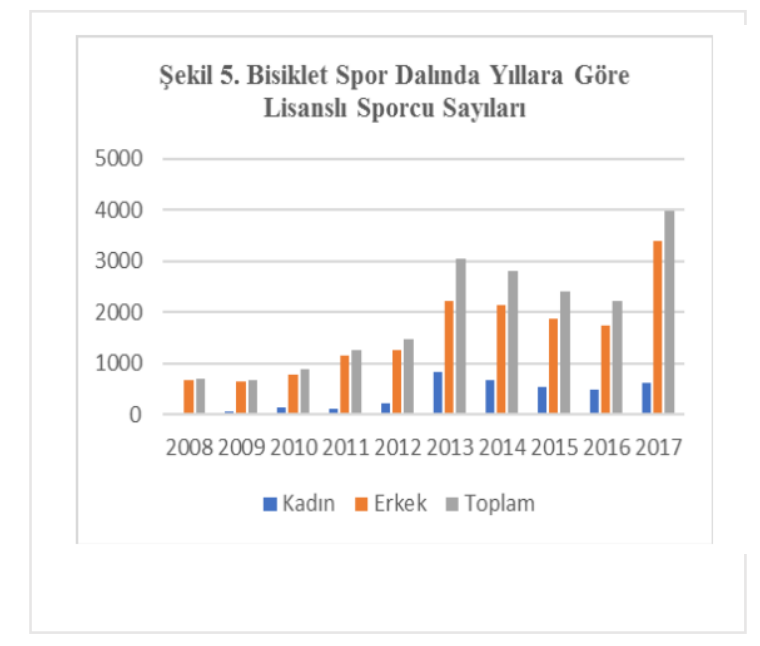

Bisiklet branşında 2007 yılına kadar 1578 kadın, 7519 erkek toplam 9097 sporcu kayıtlı görülmektedir. $\mathrm{Bu}$ branşta en 
yüksek toplam sporcu lisansı sayısına 2017 yılında ulaşılırken; en az sporcu lisansı 2009 yılında çıkarılmıştır. Kadın sporcu lisansı en yüksek düzeye 2013 yılında ulaşılırken; erkeklerde en çok lisans 2017 yılında çıkarılmıştır.

Tablo 6: Boks Spor Dalında Yillara Göre Lisanslı Sporcu Sayıları

\begin{tabular}{cccc}
\hline \multicolumn{4}{c}{ LiSANSLI SPORCU SAYISI } \\
Yıllar & Kadın & Erkek & Toplam \\
\hline 2008 & 254 & 3523 & 3777 \\
2009 & 564 & 4083 & 4647 \\
2010 & 492 & 5010 & 5502 \\
2011 & 690 & 4729 & 5419 \\
2012 & 723 & 5867 & 6590 \\
2013 & 1919 & 8202 & 10121 \\
2014 & 1352 & 6967 & 8319 \\
2015 & 1614 & 7264 & 8878 \\
2016 & 1262 & 5570 & 6832 \\
2017 & 2823 & 10696 & 13519 \\
\hline
\end{tabular}

Şekil 6. Boks Spor Dalında Yıllara Göre Lisanslı Sporcu Sayları

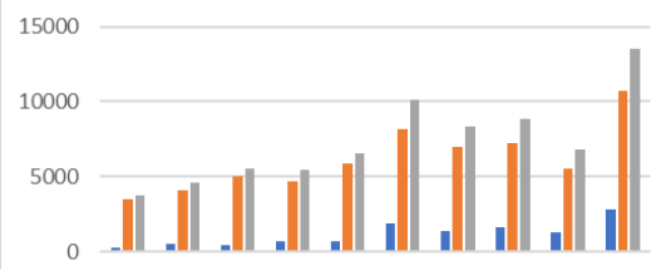
2008200920102011201220132014201520162017 -Kadın Erkek =Toplam

Boks branşında 2007 yılına kadar 2936 kadın, 31312 erkek toplam 34248 sporcu kayıtlı görülmektedir. $\mathrm{Bu}$ branşta en yüksek toplam sporcu lisansı sayısına
2017 yılında ulaşılırken; en az sporcu lisansı 2008 yılında çıkarılmıştır. Sporcu lisansları en yüksek düzeye hem kadınlarda hem de erkeklerde 2017 y1lında ulaşmıştır.

Tablo 7: Buz Hokeyi Spor Dalında Yillara Göre Lisanslı Sporcu Sayıları

\begin{tabular}{cccc}
\hline \multicolumn{4}{c}{ LISSANSLI SPORCU SAYISI } \\
Yıllar & Kadın & Erkek & Toplam \\
\hline 2008 & 104 & 232 & 336 \\
2009 & 175 & 686 & 861 \\
2010 & 35 & 214 & 249 \\
2011 & 218 & 533 & 751 \\
2012 & 229 & 625 & 854 \\
2013 & 224 & 357 & 581 \\
2014 & 82 & 108 & 190 \\
2015 & 93 & 245 & 338 \\
\hline
\end{tabular}

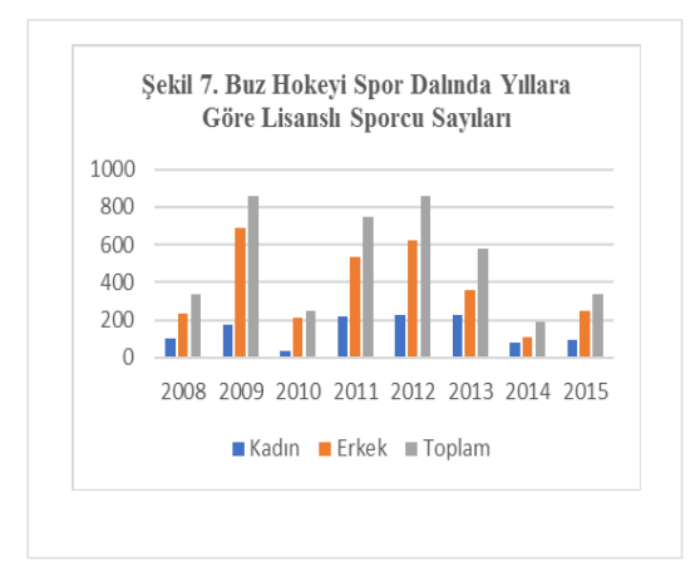

Buz Hokeyi branşında 2007 yılına kadar 983 kadın, 1484 erkek toplam 2467 sporcu kayıtlı görülmektedir. Bu branşta en yüksek toplam sporcu lisansı sayısına 2009 yılında ulaşılırken; en az sporcu lisansı 2014 yılında çıkarılmıştır. Kadın sporcu lisansı en yüksek düzeye 2012 
Ersöz, G., Alagöz, B. / Türkiye’de 2007-2017 Yılları Arasında Spor Branşları ve Cinsiyete Göre Sporcu Sayılarının Dağılımı

y1lında ulaş1lırken; erkeklerde en çok lisans 2009 yılında çıkarılmışır.

Sistemden alınan verilerde her y1 toplam sporcu sayısinın artarak devam etmesi beklenirken; bu branşta 2016 ve 2017 verilerinde sporcu lisanslarının düştüğü görülmüştür. Bu sebeple 2016 ve 2017 y1lı verileri değerlendirmeye alınmamıştır.

Tablo 8: Cimnastik Spor Dalında Yillara Göre Lisanslı Sporcu Sayıları

\begin{tabular}{cccc}
\hline \multicolumn{4}{c}{ LiSANSLI SPORCU SAYISI } \\
Yıllar & Kadın & Erkek & Toplam \\
\hline 2012 & 1854 & 822 & 2676 \\
2013 & 4920 & 3065 & 7985 \\
2014 & 5602 & 3833 & 9435 \\
2015 & 6289 & 2853 & 9142 \\
2016 & 6679 & 4041 & 10720 \\
2017 & 7870 & 4363 & 12233 \\
\hline
\end{tabular}

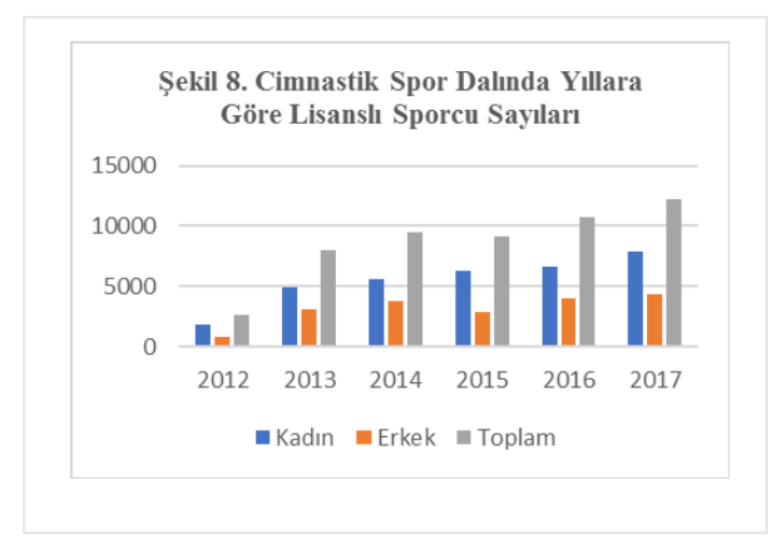

Cimnastik branşında 2007 yılına kadar 7941 kadın, 6130 erkek toplam 14071 sporcu kayitlı görülmektedir. Bu branşta en yüksek toplam sporcu lisansı sayısına 2017 yılında ulaş1lırken; en az sporcu lisansı 2012 yılında çıkarılmıştır. Sporcu lisansları en yüksek düzeye hem kadınlarda hem de erkeklerde 2017 yılında ulaşmıştır. $\mathrm{Bu}$ branşın diğer spor dallarından en önemli farkı kadın sporcuların sayısının erkeklerden fazla olmasıdır. Sistemden alınan verilerde her y1l toplam sporcu sayısının artarak devam etmesi beklenirken; bu branşta 2007 ve 2009 verilerinde sporcu lisanslarının düştüğü görülmüştür. Bu sebeple 2007, 2008 ve 2009 yılları verileri değerlendirmeye alınmamıştır.

Tablo 9: Buz Pateni Spor Dalında Yillara Göre Lisanslı Sporcu Sayıları

\begin{tabular}{cccc}
\hline \multicolumn{4}{c}{ LiSANSLI SPORCU SAYISI } \\
Yıllar & Kadın & Erkek & Toplam \\
\hline 2008 & 122 & 81 & 203 \\
2009 & 217 & 79 & 296 \\
2010 & 122 & 162 & 284 \\
2011 & 396 & 316 & 712 \\
2012 & 299 & 253 & 552 \\
2013 & 270 & 305 & 575 \\
2014 & 214 & 86 & 300 \\
2015 & 233 & 99 & 332 \\
2016 & 88 & 10 & 98 \\
2017 & 308 & 91 & 399 \\
\hline
\end{tabular}

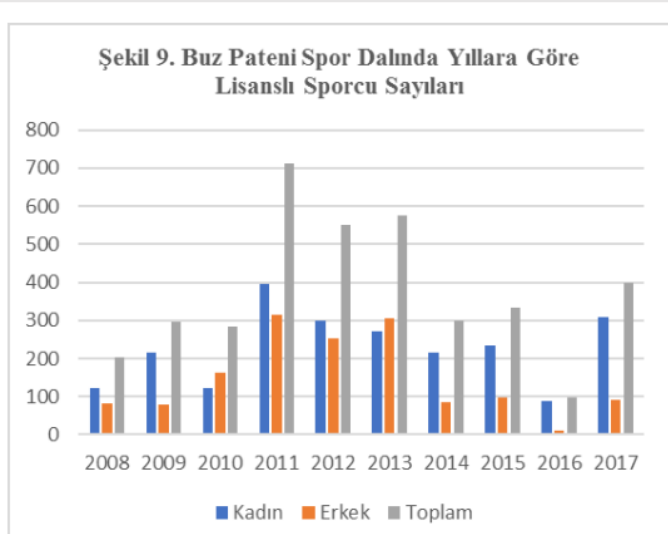


Buz Pateni branşında 2007 yılına kadar 360 kadın, 322 erkek toplam 682 sporcu kayıtlı görülmektedir. $\mathrm{Bu}$ branşta en yüksek toplam sporcu lisansı sayısına 2011 yılında ulaşılırken; en az sporcu lisansı 2016 yılında çıkarılmıştır. Sporcu lisansları en yüksek düzeye hem kadınlarda hem de erkeklerde 2011 yılında ulaşmıştır. Bu branşın diğer spor dallarından en önemli farkı kadın sporcuların sayısının, cimnastik branşındaki gibi, erkeklerden fazla olmasidır.

Tablo 10: Dağcılık Spor Dalında Yıllara Göre Lisanslı Sporcu Sayıları

\begin{tabular}{cccc}
\hline \multicolumn{4}{c}{ LISSANSLI SPORCU SAYISI } \\
Yıllar & Kadın & Erkek & Toplam \\
\hline 2008 & 441 & 1023 & 1464 \\
2009 & 320 & 1000 & 1320 \\
2010 & 566 & 1492 & 2058 \\
2011 & 679 & 1618 & 2297 \\
2012 & 788 & 1819 & 2607 \\
2013 & 785 & 1963 & 2748 \\
2014 & 805 & 1923 & 2728 \\
2015 & 1108 & 1827 & 2935 \\
2016 & 810 & 1073 & 1883 \\
2017 & 1590 & 2932 & 4522 \\
\hline
\end{tabular}

Şekil 10. Dağcılık Spor Dalında Yıllara Göre Lisansh Sporcu Sayılan

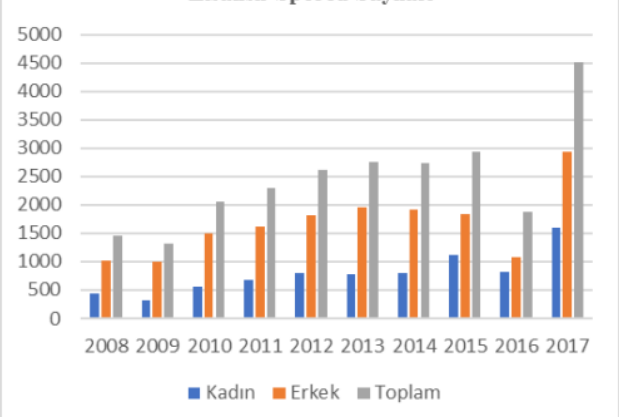

Dağcılık branşında 2007 yılına kadar 5342 kadın, 16375 erkek toplam 21717 sporcu kayıtlı görülmektedir. $\mathrm{Bu}$ branşta en yüksek toplam sporcu lisansı sayısına 2017 yılında ulaşılırken; en az sporcu lisansı 2009 yılında çıkarılmıştır. Sporcu lisansları en yüksek düzeye hem kadınlarda hem de erkeklerde 2017 yılında ulaşmıştır.

Tablo 11: Geleneksel Spor Dallarında Yıllara Göre Lisanslı Sporcu Sayıları

\begin{tabular}{cccc}
\hline \multicolumn{4}{c}{ LISANSLI SPORCU SAYISI } \\
Yıllar & Kadın & Erkek & Toplam \\
\hline 2008 & 47 & 505 & 552 \\
2009 & 26 & 602 & 628 \\
2010 & 6 & 760 & 766 \\
2011 & 77 & 921 & 998 \\
2012 & 150 & 945 & 1095 \\
2013 & 137 & 1204 & 1341 \\
2014 & 161 & 1192 & 1353 \\
2015 & 184 & 1321 & 1505 \\
2016 & 164 & 464 & 628 \\
2017 & 859 & 2816 & 3675 \\
\hline
\end{tabular}

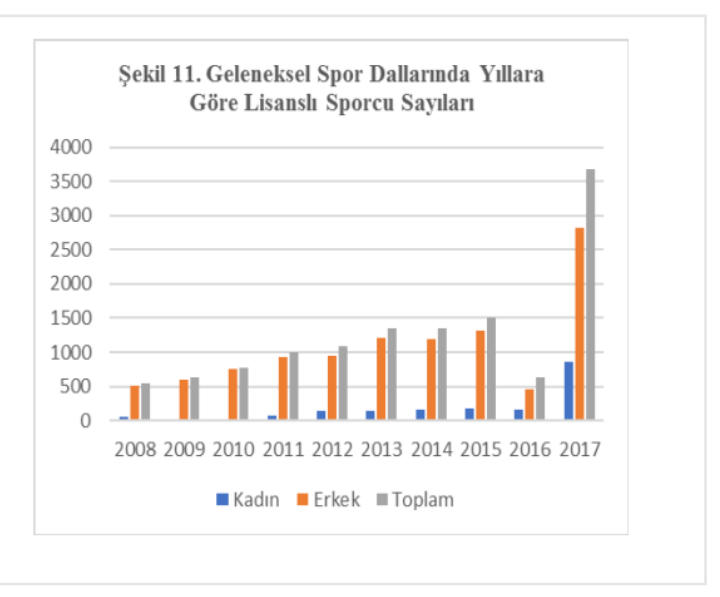


Ersöz, G., Alagöz, B. / Türkiye’de 2007-2017 Yılları Arasında Spor Branşları ve Cinsiyete Göre Sporcu Sayılarının Dağılımı

Geleneksel Spor Dalları branşında 2007 y1lına kadar 104 kadın, 3866 erkek toplam 3970 sporcu kayıtlı görülmektedir. $\mathrm{Bu}$ branşta en yüksek toplam sporcu lisansı sayısına 2017 yılında ulaşılırken; en az sporcu lisansı 2008 yılında çıkarılmıştır. Sporcu lisansları en yüksek düzeye hem kadınlarda hem de erkeklerde 2017 yılında ulaşmıştır.

Tablo 12: Görme Engelliler Spor Dalında Yıllara Göre Lisanslı Sporcu Sayıları

\begin{tabular}{cccc}
\hline \multicolumn{4}{c}{ LISANSLI SPORCU SAYISI } \\
Yıllar & Kadın & Erkek & Toplam \\
\hline 2008 & 57 & 198 & 255 \\
2009 & 66 & 263 & 329 \\
2010 & 69 & 232 & 301 \\
2011 & 73 & 213 & 286 \\
2012 & 79 & 297 & 376 \\
2013 & 106 & 286 & 392 \\
2014 & 89 & 348 & 437 \\
2015 & 130 & 280 & 410 \\
2016 & 63 & 80 & 143 \\
2017 & 86 & 220 & 306 \\
\hline
\end{tabular}

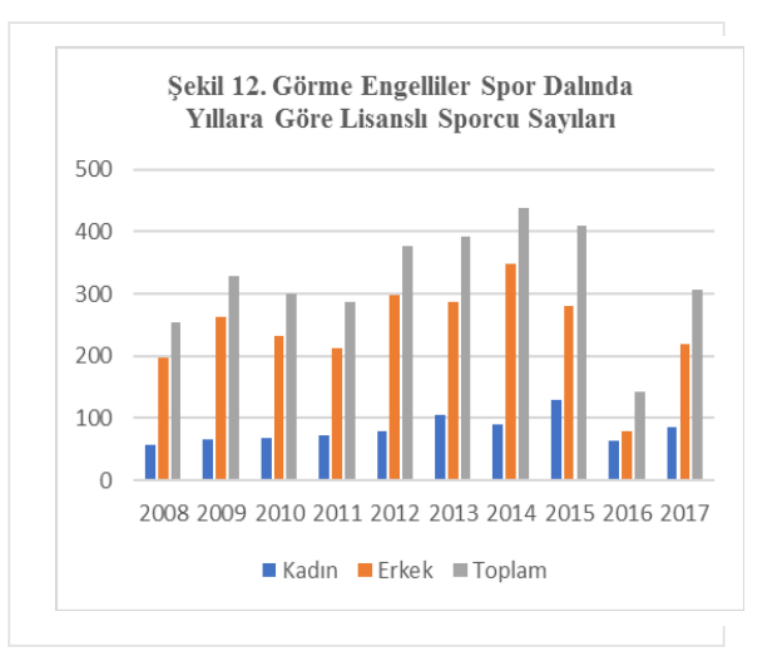

Görme Engelliler branşında 2007 y1lına kadar 396 kadın, 1524 erkek toplam 1920 sporcu kayıtlı görülmektedir. Bu branşta en yüksek toplam sporcu lisansı sayısına 2014 yılında ulaşılırken; en az sporcu lisansı 2016 yılında çıkarılmıştır. Kadın sporcu lisansı en yüksek düzeye 2015 y1lında ulaşılırken; erkeklerde en çok lisans 2014 yılında çıkarılmıştır.

Tablo 13: Güreş Spor Dalında Yıllara Göre Lisanslı Sporcu Sayıları

\begin{tabular}{cccc}
\hline \multicolumn{4}{c}{ LISANSLI SPORCU SAYISI } \\
Yıllar & Kadın & Erkek & Toplam \\
\hline 2008 & 103 & 4132 & 4235 \\
2009 & 193 & 3220 & 3413 \\
2010 & 320 & 5489 & 5809 \\
2011 & 453 & 7266 & 7719 \\
2012 & 651 & 8313 & 8964 \\
2013 & 692 & 10852 & 11544 \\
2014 & 897 & 9531 & 10428 \\
2015 & 659 & 8524 & 9183 \\
2016 & 770 & 6335 & 7105 \\
2017 & 940 & 11823 & 12763 \\
\hline
\end{tabular}

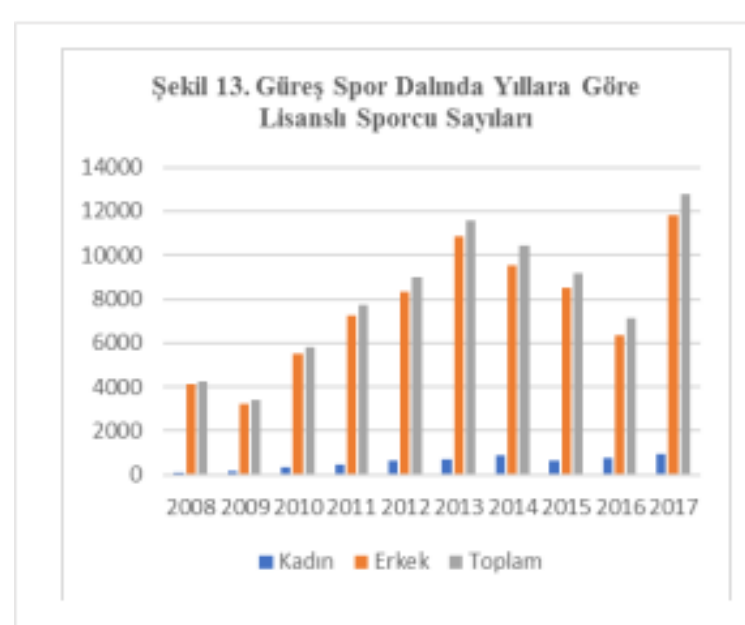

Güreş branşında 2007 yılına kadar 1287 kadın, 42422 erkek toplam 43709 sporcu 
kayıtlı görülmektedir. $\mathrm{Bu}$ branşta en yüksek toplam sporcu lisansı sayısına 2017 y1lında ulaşılırken; en az sporcu lisansı 2009 yılında çıkarılmıştır. Sporcu lisansları en yüksek düzeye hem kadınlarda hem de erkeklerde 2017 yılında ulaşmıştır.

Tablo 14: Halk Oyunları Spor Dalında Yıllara Göre Lisanslı Sporcu Sayıları

\begin{tabular}{cccc}
\hline \multicolumn{4}{c}{ LiSANSLI SPORCU SAYISI } \\
Yıllar & Kadın & Erkek & Toplam \\
\hline 2008 & 3138 & 2276 & 5414 \\
2009 & 3252 & 2513 & 5765 \\
2010 & 4952 & 3331 & 8283 \\
2011 & 4819 & 3376 & 8195 \\
2012 & 6984 & 4939 & 11923 \\
2013 & 6630 & 3760 & 10390 \\
2014 & 5575 & 3818 & 9393 \\
2015 & 5338 & 2085 & 7423 \\
2016 & 3339 & 1137 & 4476 \\
2017 & 6047 & 3673 & 9720 \\
\hline
\end{tabular}

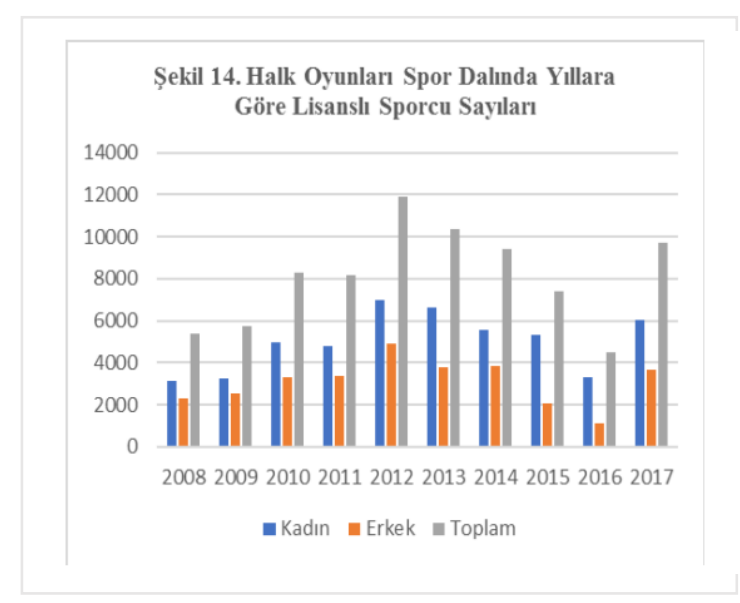

Halk Oyunları branşında 2007 yılına kadar 23957 kadın, 19757 erkek toplam 43714 sporcu kayıtlı görülmektedir. $\mathrm{Bu}$ branşta en yüksek toplam sporcu lisansı sayısına 2012 yılında ulaşılırken; en az sporcu lisansı 2016 yılında çıkarılmıştır. Sporcu lisansları en yüksek düzeye hem kadınlarda hem de erkeklerde 2012 y1lında ulaşmıştır. Bu branşın diğer spor dallarından en önemli farkı kadın sporcuların sayısının erkeklerden fazla olmasidır.

Tablo 15: Halter Spor Dalında Yillara Göre Lisanslı Sporcu Sayıları

\begin{tabular}{cccc}
\hline \multicolumn{4}{c}{ LISANSLI SPORCU SAYISI } \\
Yıllar & Kadın & Erkek & Toplam \\
\hline 2008 & 25 & 445 & 470 \\
2009 & 54 & 401 & 455 \\
2010 & 59 & 253 & 312 \\
2011 & 90 & 268 & 358 \\
2012 & 74 & 429 & 503 \\
2013 & 136 & 537 & 673 \\
2014 & 258 & 818 & 1076 \\
2015 & 390 & 818 & 1208 \\
2016 & 272 & 527 & 799 \\
2017 & 291 & 859 & 1150 \\
\hline
\end{tabular}

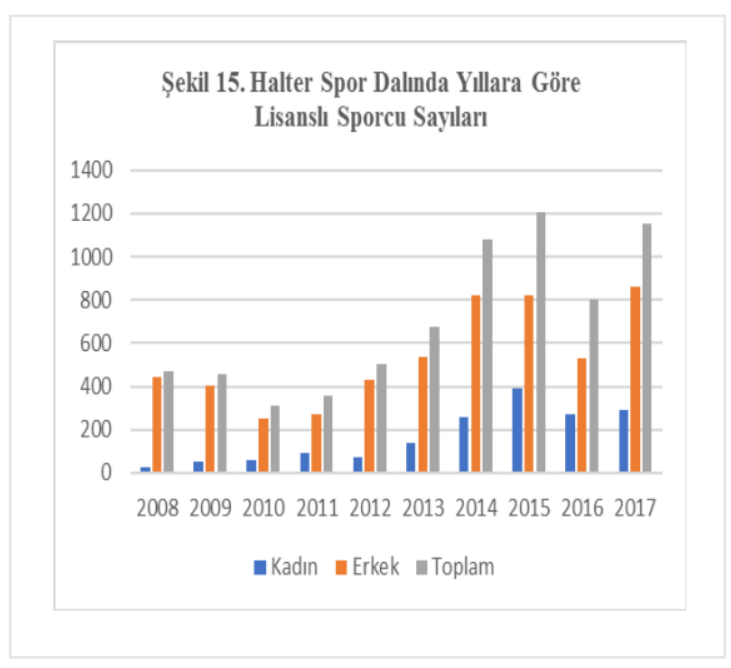

Halter branşında 2007 yılına kadar 749 kadın, 4218 erkek toplam 4967 sporcu kayıtlı görülmektedir. $\mathrm{Bu}$ branşta en 
Ersöz, G., Alagöz, B. / Türkiye’de 2007-2017 Yılları Arasında Spor Branşları ve Cinsiyete Göre Sporcu Sayılarının Dağılımı

yüksek toplam sporcu lisansı sayısına 2015 yılında ulaşılırken; en az sporcu lisansı 2010 yılında çıkarılmıştır. Kadın sporcu lisansı en yüksek düzeye 2015 yılında ulaşılırken; erkeklerde en çok lisans 2017 yılında çıkarılmıştır.

Tablo 16: Hentbol Spor Dalında Yillara Göre Lisanslı Sporcu Sayıları

\begin{tabular}{cccc}
\hline \multicolumn{4}{c}{ LISANSLI SPORCU SAYISI } \\
Yıllar & Kadın & Erkek & Toplam \\
\hline 2008 & 1211 & 2695 & 3906 \\
2009 & 1163 & 2242 & 3405 \\
2010 & 1742 & 3134 & 4876 \\
2011 & 1931 & 4170 & 6101 \\
2012 & 2622 & 4638 & 7260 \\
2013 & 3367 & 5347 & 8714 \\
2014 & 2723 & 3989 & 6712 \\
2015 & 2529 & 2796 & 5325
\end{tabular}

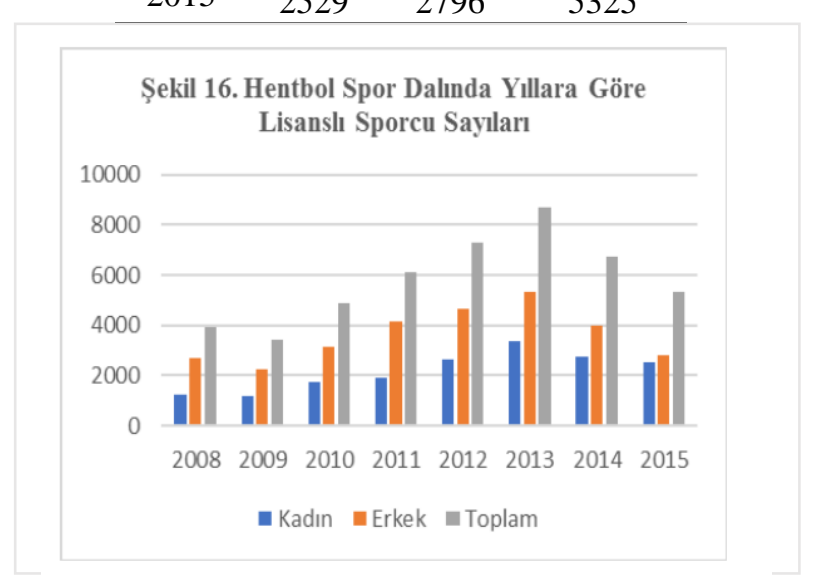

Hentbol branşında 2007 y1lına kadar 18707 kadın, 38237 erkek toplam 56944 sporcu kayıtlı görülmektedir. Bu branşta en yüksek toplam sporcu lisansı sayısına 2013 yılında ulaşılırken; en az sporcu lisansı 2009 yılında çıkarılmıştır. Sporcu lisansları en yüksek düzeye hem kadınlarda hem de erkeklerde 2013 yılında ulaşmıştır. Sistemden alınan verilerde her y1l toplam sporcu sayısının artarak devam etmesi beklenirken; bu branşta 2016 ve 2017 verilerinde sporcu lisanslarının düştüğü görülmüştür. $\mathrm{Bu}$ sebeple 2016 ve 2017 yılları verileri değerlendirmeye alınmamıştır.

Tablo 17: Herkes İçin Spor Dalında Yıllara Göre Lisanslı Sporcu Sayıları

\begin{tabular}{cccc}
\hline \multicolumn{4}{c}{ LISSANSLI SPORCU SAYISI } \\
Yıllar & Kadın & Erkek & Toplam \\
\hline 2008 & 253 & 1072 & 1325 \\
2009 & 471 & 576 & 1047 \\
2010 & 428 & 3390 & 3818 \\
2011 & 303 & 1874 & 2177 \\
2012 & 10572 & 19241 & 29813 \\
2013 & 20724 & 29951 & 50675 \\
2014 & 8623 & 15647 & 24270 \\
2015 & 3697 & 5263 & 8960 \\
2016 & 4716 & 9513 & 14229 \\
2017 & 5800 & 10937 & 16737 \\
\hline
\end{tabular}

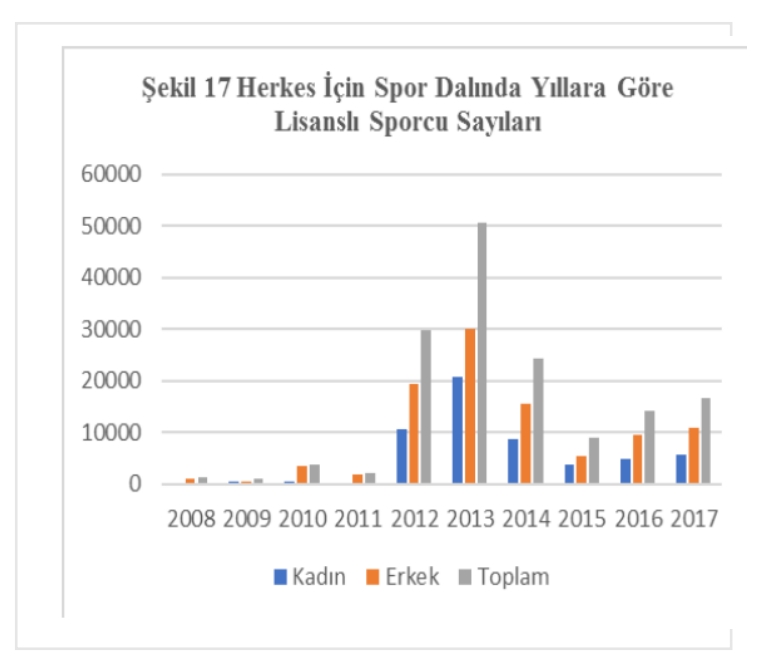

Herkes İçin Spor branşında 2007 yılına kadar 8753 kadın, 12288 erkek toplam 21041 sporcu kayıtlı görülmektedir. Bu 
branşta en yüksek toplam sporcu lisansı sayısına 2013 yılında ulaşılırken; en az sporcu lisansı 2009 yılında çıkarılmıştır. Sporcu lisansları en yüksek düzeye hem kadınlarda hem de erkeklerde 2013 yılında ulaşmıştır.

Tablo 18: İşitme Engelliler Spor Dalında Yıllara Göre Lisanslı Sporcu Sayıları

\begin{tabular}{cccc}
\hline \multicolumn{4}{c}{ LISANSLI SPORCU SAYISI } \\
Yıllar & Kadın & Erkek & Toplam \\
\hline 2008 & 100 & 407 & 507 \\
2009 & 81 & 379 & 460 \\
2010 & 158 & 364 & 522 \\
2011 & 148 & 473 & 621 \\
2012 & 179 & 496 & 675 \\
2013 & 121 & 492 & 613 \\
2014 & 54 & 378 & 432 \\
2015 & 192 & 302 & 494 \\
\hline
\end{tabular}

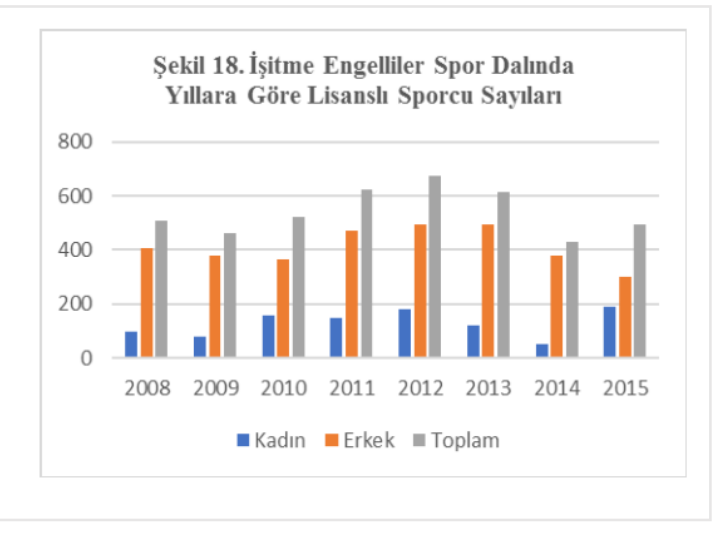

İşitme Engelliler branşında 2007 y1lına kadar 694 kadın, 5241 erkek toplam 5935 sporcu kayıtlı görülmektedir. Bu branşta en yüksek toplam sporcu lisansı sayısına 2012 yılında ulaşılırken; en az sporcu lisansı 2014 yılında çıkarılmıştır. Sporcu lisansları en yüksek düzeye kadınlarda
2015 yılında; erkeklerde ise 2012 yılında gelmiştir. Sistemden alınan verilerde her y1l toplam sporcu sayısının artarak devam etmesi beklenirken; bu branşta 2016 ve 2017 verilerinde sporcu lisanslarının düştüğü görülmüştür. Bu sebeple 2016 ve 2017 yılları verileri değerlendirmeye alınmamıştır.

Tablo 19: Judo Spor Dalında Yillara Göre Lisanslı Sporcu Sayıları

\begin{tabular}{cccc}
\hline \multicolumn{4}{c}{ LISANSLI SPORCU SAYISI } \\
Yıllar & Kadın & Erkek & Toplam \\
\hline 2008 & 660 & 1369 & 2029 \\
2009 & 523 & 1040 & 1563 \\
2010 & 887 & 1887 & 2774 \\
2011 & 1431 & 2922 & 4353 \\
2012 & 2255 & 3839 & 6094 \\
2013 & 4246 & 6550 & 10796 \\
2014 & 2840 & 5559 & 8399 \\
2015 & 3696 & 5577 & 9273 \\
2016 & 3289 & 4353 & 7642 \\
2017 & 4338 & 6515 & 10853 \\
\hline
\end{tabular}

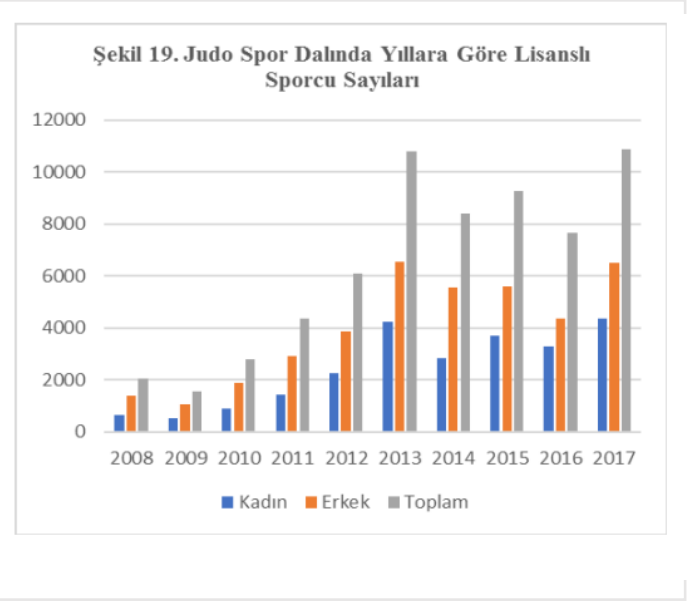

Judo branşında 2007 yılına kadar 7937 kadın, 24521 erkek toplam 32458 sporcu 
Ersöz, G., Alagöz, B. / Türkiye’de 2007-2017 Yılları Arasında Spor Branşları ve Cinsiyete Göre Sporcu Sayılarının Dağılımı

kayıtlı görülmektedir. $\mathrm{Bu}$ branşta en yüksek toplam sporcu lisansı sayısına 2017 yılında ulaşılırken; en az sporcu lisansı 2009 yılında çıkarılmıştır. Sporcu lisansları en yüksek düzeye kadınlarda 2017 y1lında; erkeklerde ise 2013 y1lında gelmiştir.

Tablo 20: Kano-Rafting Spor Dalında Yillara Göre Lisanslı Sporcu Sayıları

\begin{tabular}{cccc}
\hline \multicolumn{4}{c}{ LISANSLI SPORCU SAYISI } \\
Yıllar & Kadın & Erkek & Toplam \\
\hline 2008 & 87 & 193 & 280 \\
2009 & 51 & 112 & 163 \\
2010 & 88 & 198 & 286 \\
2011 & 101 & 265 & 366 \\
2012 & 40 & 120 & 160 \\
2013 & 545 & 1391 & 1936 \\
2014 & 442 & 1092 & 1534 \\
2015 & 315 & 509 & 824 \\
2016 & 60 & 50 & 110 \\
2017 & 110 & 260 & 370 \\
\hline
\end{tabular}

Şekil 20. Kano-RaftingSpor Dalında Yıllara Göre Lisanslı Sporcu Sayları

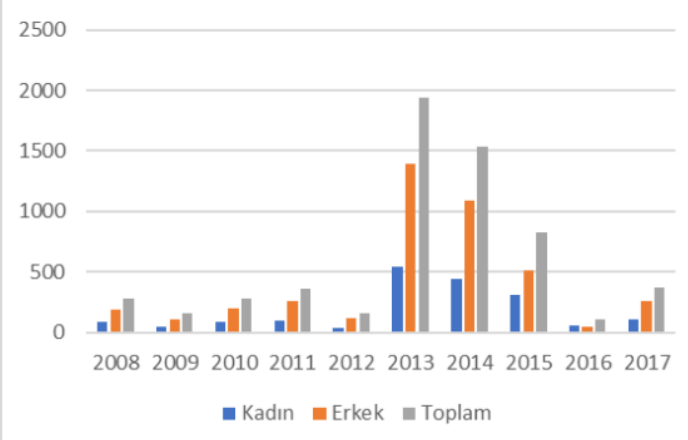

Kano-Rafting branşında 2007 yılına kadar 439 kadın, 2328 erkek toplam 2767 sporcu kayıtlı görülmektedir. Bu branşta en yüksek toplam sporcu lisansı sayısına 2013 y1lında ulaşılırken; en az sporcu lisansı 2016 yılında çıkarılmıştır. Sporcu lisansları en yüksek düzeye hem kadınlarda hem de erkeklerde 2013 yılında ulaşmıştır.

Tablo 21: Karate Spor Dalında Yillara Göre Lisanslı Sporcu Sayıları

\begin{tabular}{cccc}
\hline \multicolumn{4}{c}{ LISANSLI SPORCU SAYISI } \\
Yıllar & Kadın & Erkek & Toplam \\
\hline 2008 & 1585 & 4552 & 6137 \\
2009 & 2936 & 6812 & 9748 \\
2010 & 3570 & 8576 & 12146 \\
2011 & 4413 & 10568 & 14981 \\
2012 & 6848 & 14902 & 21750 \\
2013 & 6830 & 12540 & 19370 \\
2014 & 4604 & 8189 & 12793 \\
2015 & 5038 & 8572 & 13610 \\
2016 & 4266 & 5892 & 10158 \\
2017 & 6933 & 11957 & 18890 \\
\hline
\end{tabular}

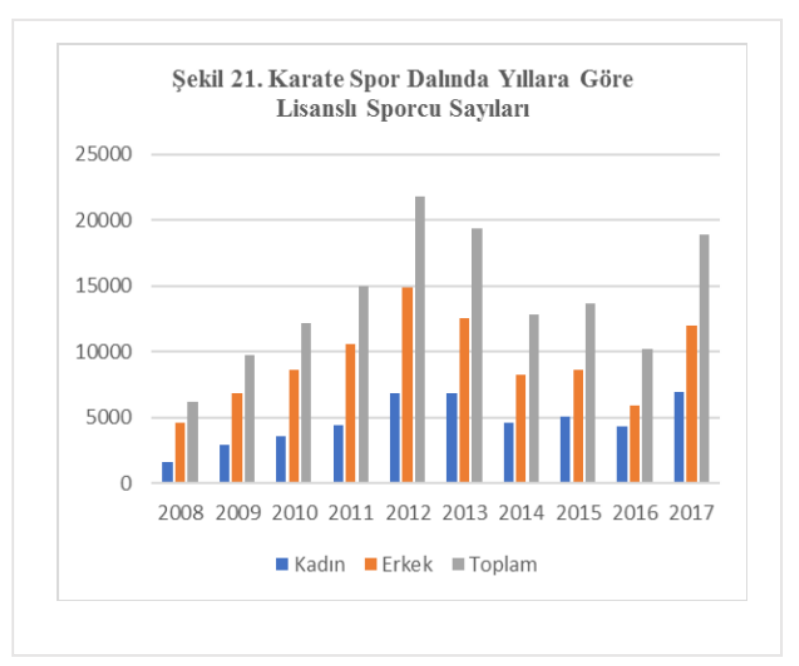

Karate branşında 2007 yılına kadar 14632 kadın, 47043 erkek toplam 61675 sporcu kayıtlı görülmektedir. $\mathrm{Bu}$ branşta en 
yüksek toplam sporcu lisansı sayısına 2012 yılında ulaşılırken; en az sporcu lisansı 2008 yılında çıkarılmıştır. Sporcu lisansları en yüksek düzeye kadınlarda 2017 y1lında; erkeklerde ise 2012 y1lında gelmiştir.

Tablo 22: Kayak Spor Dalında Yillara Göre Lisanslı Sporcu Sayıları

\begin{tabular}{cccc}
\hline \multicolumn{4}{c}{ LISSANSLI SPORCU SAYISI } \\
Yıllar & Kadın & Erkek & Toplam \\
\hline 2008 & 303 & 766 & 1069 \\
2009 & 335 & 1364 & 1699 \\
2010 & 476 & 1198 & 1674 \\
2011 & 496 & 1152 & 1648 \\
2012 & 453 & 1028 & 1481 \\
2013 & 612 & 1381 & 1993 \\
2014 & 398 & 836 & 1234 \\
2015 & 664 & 938 & 1602 \\
2016 & 530 & 657 & 1187 \\
2017 & 766 & 1292 & 2058 \\
\hline
\end{tabular}

Kayak branşında 2007 yılına kadar 3807 kadın, 12188 erkek toplam 15995 sporcu kayıtlı görülmektedir. $\mathrm{Bu}$ branşta en yüksek toplam sporcu lisansı sayısına 2017 yılında ulaşılırken; en az sporcu lisansı 2008 yılında çıkarılmıştır. Sporcu lisansları en yüksek düzeye kadınlarda 2017 y1lında; erkeklerde ise 2013 yılında gelmiştir.

Tablo 23: Kick Boks Spor Dalında Yıllara Göre Lisanslı Sporcu Sayıları

\begin{tabular}{cccc}
\hline \multicolumn{4}{c}{ LiSANSLI SPORCU SAYISI } \\
YIllar & Kadın & Erkek & Toplam \\
\hline 2012 & 2115 & 11556 & 13671 \\
2013 & 2873 & 12784 & 15657 \\
2014 & 3043 & 14476 & 17519 \\
2015 & 4505 & 19123 & 23628 \\
2016 & 5243 & 19059 & 24302 \\
2017 & 7663 & 21772 & 29435 \\
\hline
\end{tabular}

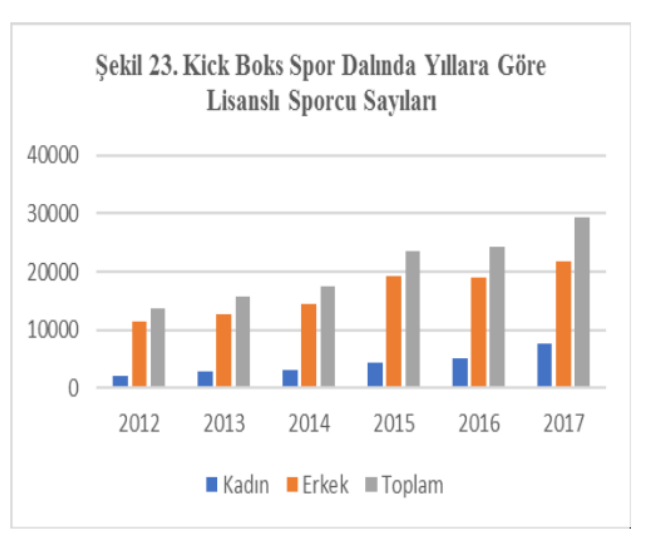

Kick Boks branşında 2007 yılına kadar 4746 kadın, 30129 erkek toplam 34875 sporcu kayıtlı görülmektedir. Bu branşta en yüksek toplam sporcu lisansı sayısına 2017 yılında ulaşılırken; en az sporcu lisansı 2012 yılında çıkarılmıştır. Sporcu lisansları en yüksek düzeye hem kadınlarda hem de erkeklerde 2017 
Ersöz, G., Alagöz, B. / Türkiye'de 2007-2017 Yılları Arasında Spor Branşları ve Cinsiyete Göre Sporcu Sayılarının Dağılımı

yılında ulaşmıştır. Sistemden alınan verilerde her yll toplam sporcu sayısının artarak devam etmesi beklenirken; bu branşta 2011 verilerinde sporcu lisanslarının düştüğü görülmüştür. Bu sebeple 2008, 2009, 2010 ve 2011 yillar1 verileri değerlendirmeye alınmamıştır.

Tablo 24: Masa Tenisi Spor Dalında Yillara Göre Lisanslı Sporcu Sayıları

\begin{tabular}{cccc}
\hline \multicolumn{4}{c}{ LISSANSLI SPORCU SAYISI } \\
Yıllar & Kadın & Erkek & Toplam \\
\hline 2008 & 963 & 2882 & 3845 \\
2009 & 653 & 1812 & 2465 \\
2010 & 826 & 2271 & 3097 \\
2011 & 1554 & 3802 & 5356 \\
2012 & 2914 & 5903 & 8817 \\
2013 & 7157 & 10718 & 17875 \\
2014 & 5129 & 7353 & 12482 \\
2015 & 3303 & 4411 & 7714 \\
2016 & 1526 & 1775 & 3301 \\
2017 & 3785 & 6032 & 9817 \\
\hline
\end{tabular}

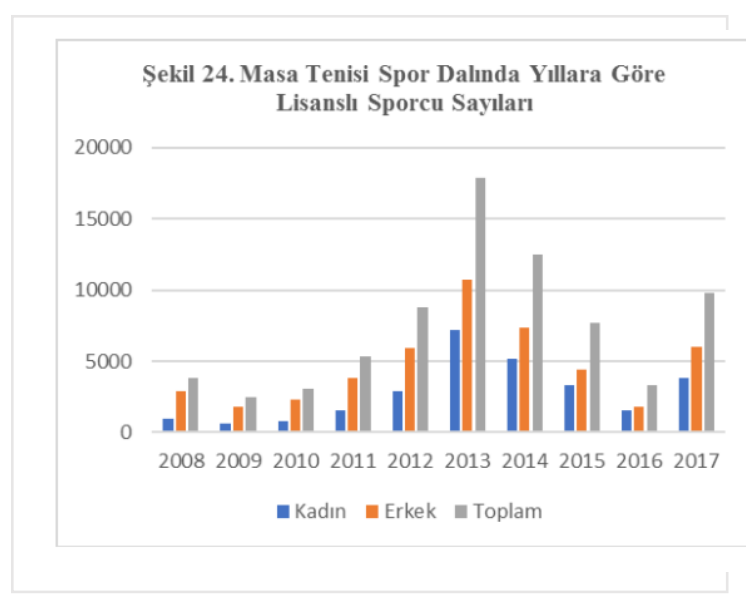

Masa Tenisi branşında 2007 yılına kadar 13053 kadın, 32737 erkek toplam 45790 sporcu kayıtlı görülmektedir. Bu branşta en yüksek toplam sporcu lisansı sayısına
2013 yılında ulaş1lırken; en az sporcu lisans1 2009 yılında çıkarılmıştır. Sporcu lisansları en yüksek düzeye hem kadınlarda hem de erkeklerde 2013 yılında ulaşmıştır.

Tablo 25: Modern Pentatlon Spor Dalında Yıllara Göre Lisanslı Sporcu Sayıları

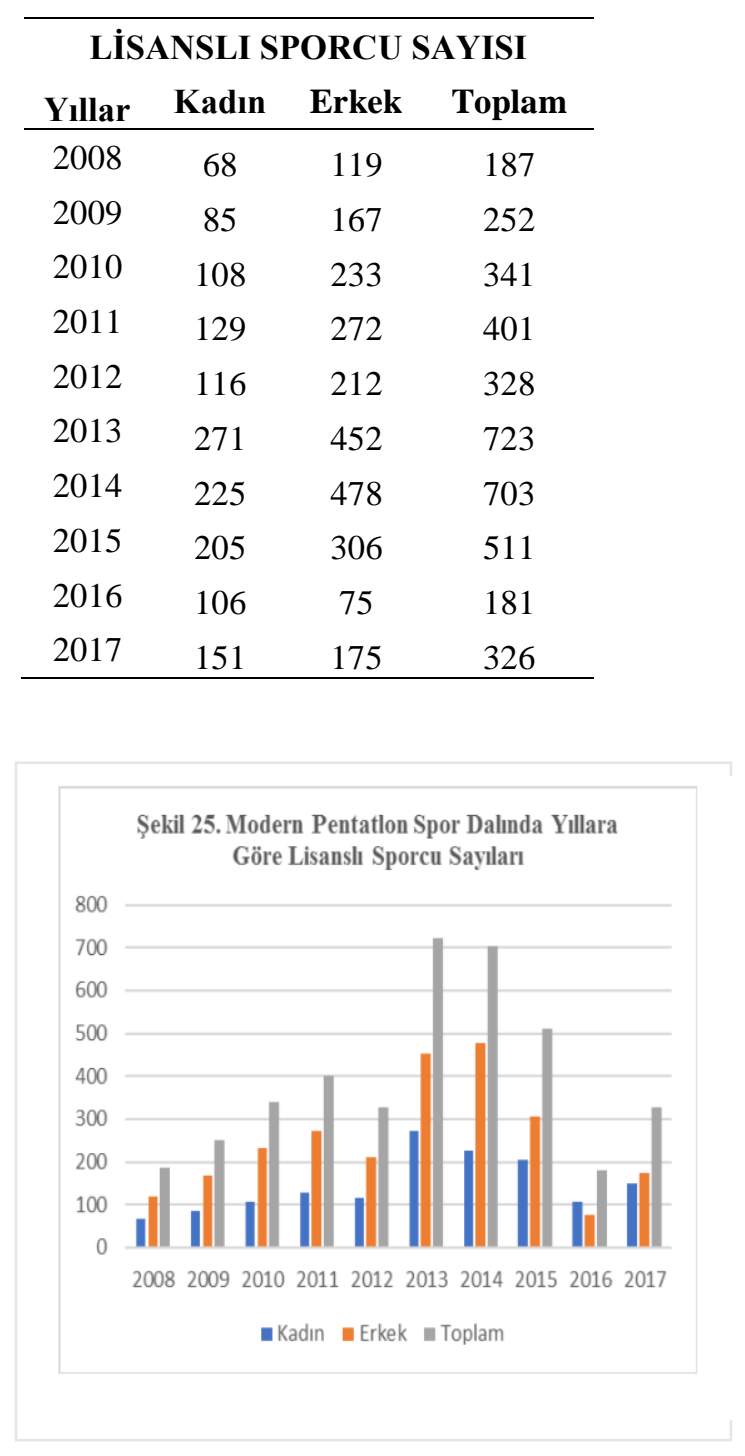

Modern Pentatlon branşında 2007 yılına kadar 200 kadın, 524 erkek toplam 724 sporcu kayıtlı görülmektedir. Bu branşta en yüksek toplam sporcu lisansı sayısına 
2013 yılında ulaşılırken; en az sporcu lisansı 2016 yılında çıkarılmıştır. Sporcu lisansları en yüksek düzeye kadınlarda 2013 y1lında; erkeklerde ise 2014 y1lında gelmiştir.

Tablo 26: Muay-Thai Spor Dalında Yıllara Göre Lisanslı Sporcu Sayıları

\begin{tabular}{cccc}
\hline \multicolumn{4}{c}{ LiSANSLI SPORCU SAYISI } \\
Yillar & Kadın & Erkek & Toplam \\
\hline 2008 & 631 & 4010 & 4641 \\
2009 & 678 & 4660 & 5338 \\
2010 & 600 & 4056 & 4656 \\
2011 & 937 & 5138 & 6075 \\
2012 & 1411 & 7345 & 8756 \\
2013 & 1719 & 8591 & 10310 \\
2014 & 2171 & 9668 & 11839 \\
2015 & 1710 & 6359 & 8069 \\
2016 & 1862 & 5934 & 7796 \\
2017 & 3150 & 8877 & 12027 \\
\hline
\end{tabular}

Şekil 26. Muay-Thai Spor Dalında Yıllara Göre Lisanslı Sporcu Sayları

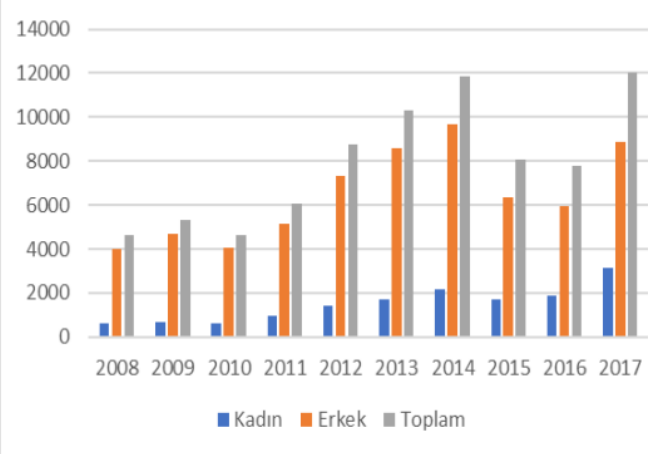

Muay-Thai branşında 2007 yılına kadar 778 kadın, 4031 erkek toplam 4809 sporcu kayıtlı görülmektedir. Bu branşta en yüksek toplam sporcu lisansı sayısına 2017 yılında ulaşılırken; en az sporcu lisansı 2008 yılında çıkarılmıştır. Sporcu lisansları en yüksek düzeye kadınlarda 2017 yılında; erkeklerde ise 2014 y1lında gelmiştir.

Tablo 27: Okçuluk Spor Dalında Yillara Göre Lisanslı Sporcu Sayıları

\begin{tabular}{cccc}
\hline \multicolumn{4}{c}{ LiSANSLI SPORCU SAYISI } \\
Yıllar & Kadın & Erkek & Toplam \\
\hline 2008 & 189 & 469 & 658 \\
2009 & 169 & 377 & 546 \\
2010 & 231 & 553 & 784 \\
2011 & 300 & 627 & 927 \\
2012 & 424 & 995 & 1419 \\
2013 & 926 & 1871 & 2797 \\
2014 & 856 & 1582 & 2438 \\
2015 & 1158 & 1527 & 2685 \\
2016 & 1497 & 1902 & 3399 \\
2017 & 2525 & 3531 & 6056 \\
\hline
\end{tabular}

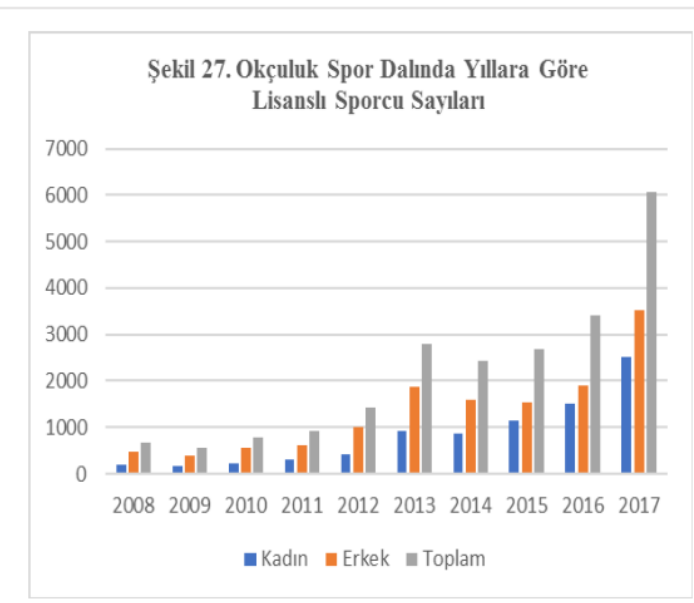

Okçuluk branşında 2007 yılına kadar 2285 kadın, 4007 erkek toplam 6292 sporcu kayıtlı görülmektedir. $\mathrm{Bu}$ branşta en yüksek toplam sporcu lisansı sayısına 2017 yılında ulaşılırken; en az sporcu lisansı 2009 yılında çıkarılmıştır. Sporcu 
Ersöz, G., Alagöz, B. / Türkiye’de 2007-2017 Yılları Arasında Spor Branşları ve Cinsiyete Göre Sporcu Sayılarının Dağılımı

lisansları en yüksek düzeye hem kadınlarda hem de erkeklerde 2017 kadınlarda hem de erkeklerde $2017 \quad$ yılında ulaşmıştır.

yılında ulaşmıştır.

Tablo 29: Sutopu Spor Dalında Yillara Göre Lisanslı Sporcu Sayıları

Tablo 28: Oryantring Spor Dalında Yillara Göre Lisanslı Sporcu Sayıları

\begin{tabular}{cccc}
\hline \multicolumn{4}{c}{ LISANSLI SPORCU SAYISI } \\
Yıllar & Kadın & Erkek & Toplam \\
\hline 2008 & 105 & 470 & 575 \\
2009 & 88 & 358 & 446 \\
2010 & 114 & 413 & 527 \\
2011 & 180 & 494 & 674 \\
2012 & 177 & 636 & 813 \\
2013 & 354 & 752 & 1106 \\
2014 & 257 & 684 & 941 \\
2015 & 345 & 738 & 1083 \\
2016 & 235 & 592 & 827 \\
2017 & 402 & 990 & 1392 \\
\hline
\end{tabular}

\begin{tabular}{cccc}
\hline \multicolumn{4}{c}{ LiSANSLI SPORCU SAYISI } \\
Yıllar & Kadın & Erkek & Toplam \\
\hline 2008 & 202 & 467 & 669 \\
2009 & 210 & 550 & 760 \\
2010 & 322 & 616 & 938 \\
2011 & 434 & 899 & 1333 \\
2012 & 485 & 1020 & 1505 \\
2013 & 766 & 1392 & 2158 \\
2014 & 832 & 1188 & 2020 \\
2015 & 1213 & 1303 & 2516 \\
2016 & 885 & 951 & 1836 \\
2017 & 1878 & 2173 & 4051 \\
\hline
\end{tabular}

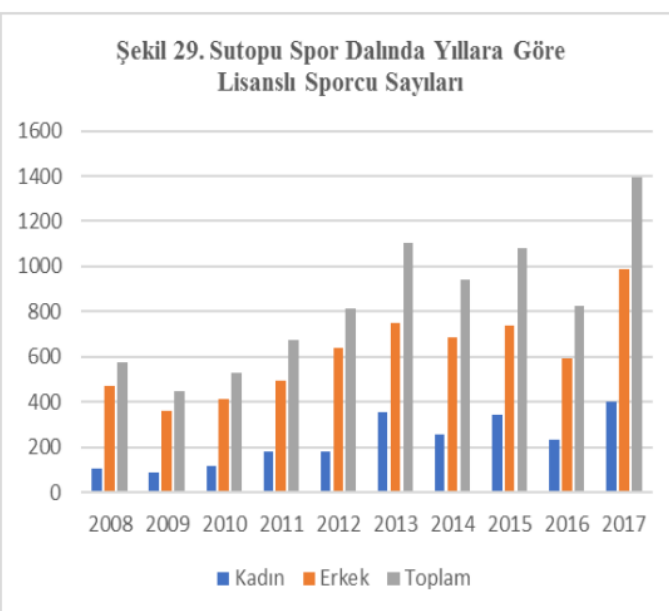

Oryantring branşında 2007 yılına kadar 331 kadın, 833 erkek toplam 1164 sporcu kayıtlı görülmektedir. $\mathrm{Bu}$ branşta en yüksek toplam sporcu lisansı sayısına 2017 y1lında ulaşılırken; en az sporcu lisansı 2008 yılında çıkarılmıştır. Sporcu lisansları en yüksek düzeye hem

Sutopu branşında 2007 yılına kadar 419 kadın, 1893 erkek toplam 2312 sporcu kayıtlı görülmektedir. $\mathrm{Bu}$ branşta en yüksek toplam sporcu lisansı sayısına 2017 yılında ulaşılırken; en az sporcu lisansı 2009 yılında çıkarılmıştır. Sporcu lisansları en yüksek düzeye hem 
kadınlarda hem de erkeklerde 2017

yılında ulaşmıştır.

Tablo 30: Taekwondo Spor Dalında Yillara Göre Lisanslı Sporcu Sayıları

\begin{tabular}{cccc}
\hline \multicolumn{4}{c}{ LISSANSLI SPORCU SAYISI } \\
Yıllar & Kadın & Erkek & Toplam \\
\hline 2011 & 6168 & 54191 & 60359 \\
2012 & 8561 & 17714 & 26275 \\
2013 & 10412 & 17634 & 28046 \\
2014 & 9560 & 17426 & 26986 \\
2015 & 10569 & 16655 & 27224 \\
2016 & 11892 & 14528 & 26420 \\
2017 & 18598 & 24660 & 43258 \\
\hline
\end{tabular}

Taekwondo branşında 2007 yılına kadar 37303 kadın, 120413 erkek toplam 157716 sporcu kayıtlı görülmektedir. Bu branşta en yüksek toplam sporcu lisansı sayısına 2011 yılında ulaş1lırken; en az sporcu lisansı 2012 yılında çıkarılmıştır. Sporcu lisansları en yüksek düzeye kadınlarda 2017 yılında; erkeklerde ise 2011 yılında gelmiştir.

Tablo 31: Triatlon Spor Dalında Y1llara Göre Lisanslı Sporcu Sayıları

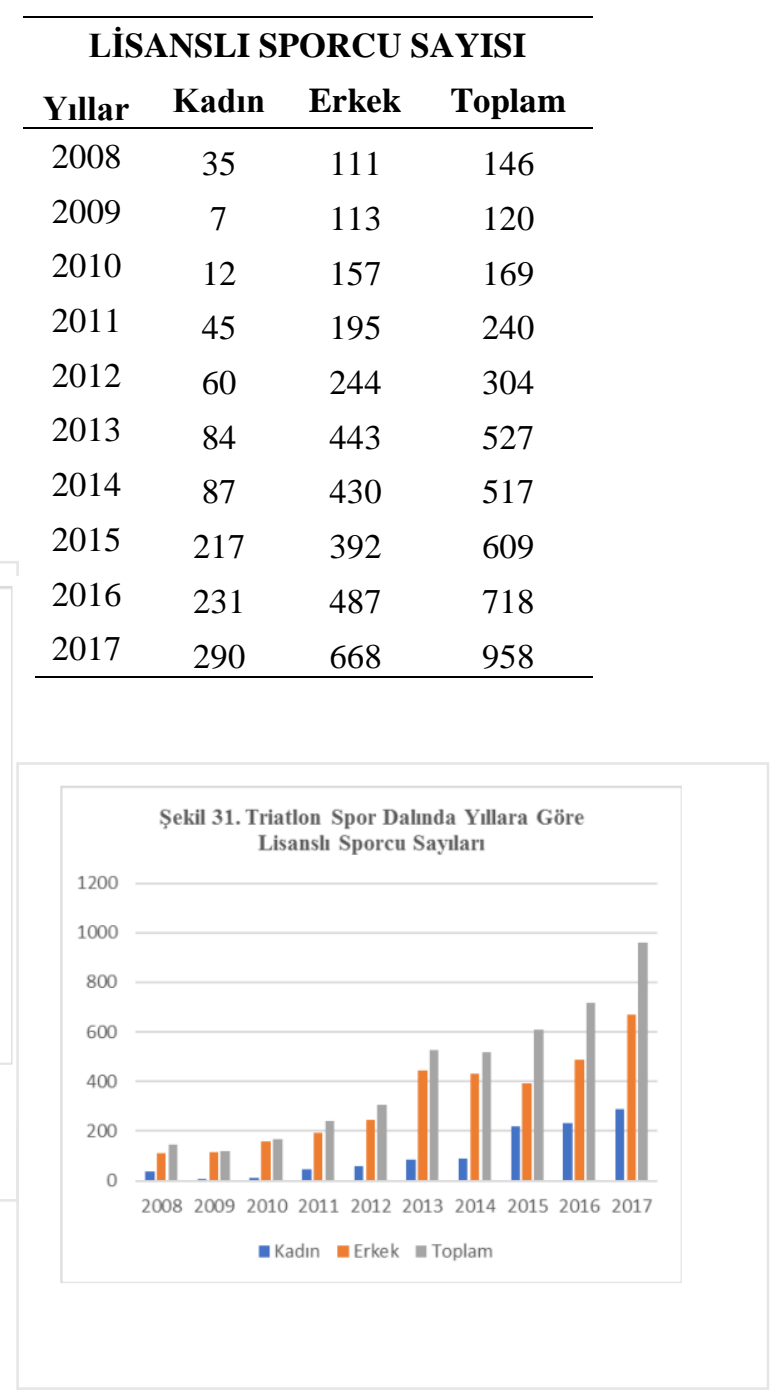

Triatlon branşında 2007 yılına kadar 371 kadın, 1181 erkek toplam 1552 sporcu kayıtlı görülmektedir. $\mathrm{Bu}$ branşta en yüksek toplam sporcu lisansı sayısına 2017 yılında ulaşılırken; en az sporcu lisansı 2009 yılında çıkarılmıştır. Sporcu 
Ersöz, G., Alagöz, B. / Türkiye'de 2007-2017 Yılları Arasında Spor Branşları ve Cinsiyete Göre Sporcu Sayılarının Dağılımı

lisansları en yüksek düzeye hem kadınlarda hem de erkeklerde 2017 yılında ulaşmıştır.

Tablo 32: Voleybol Spor Dalında Yıllara Göre Lisanslı Sporcu Sayıları

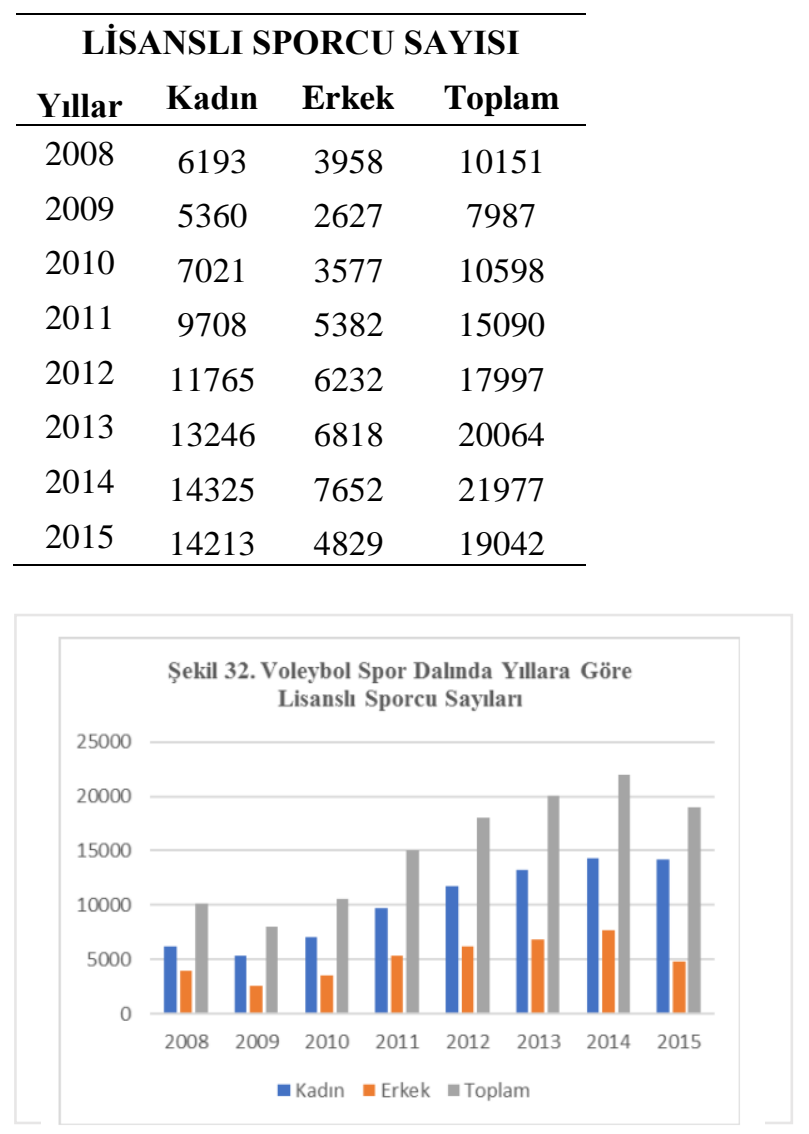

Voleybol branşında 2007 yılına kadar 55116 kadın, 55377 erkek toplam 24041 sporcu kayıtlı görülmektedir. Bu branşta en yüksek toplam sporcu lisansı sayısına 2014 y1lında ulaşılırken; en az sporcu lisansı 2009 yılında çıkarılmıştır. Sporcu lisansları en yüksek düzeye hem kadınlarda hem de erkeklerde 2014 yılında ulaşmıştır. Bu branşın diğer spor dallarından en önemli farkı kadın sporcuların sayısının erkeklerden fazla olmasıdır. Voleybol spor dalında 2007 yılına kadar erkeklerin lisansı fazla iken, 2008 yılı itibarıla kadın sporcu sayılarında artış başlamış ve yıllar geçtikçe devam etmiştir.

Tablo 33: Vücut Geliştirme ve Fitness Spor Dalında Yıllara Göre Lisanslı Sporcu Sayıları

\begin{tabular}{cccc}
\hline \multicolumn{4}{c}{ LISANSLI SPORCU SAYISI } \\
Yıllar & Kadın & Erkek & Toplam \\
\hline 2008 & 277 & 1893 & 2170 \\
2009 & 471 & 1775 & 2246 \\
2010 & 354 & 1387 & 1741 \\
2011 & 589 & 1211 & 1800 \\
2012 & 585 & 1878 & 2463 \\
2013 & 3598 & 3389 & 6987 \\
2014 & 1168 & 4592 & 5760 \\
2015 & 1814 & 4349 & 6163 \\
2016 & 1636 & 3111 & 4747 \\
2017 & 1412 & 3006 & 4418 \\
\hline
\end{tabular}

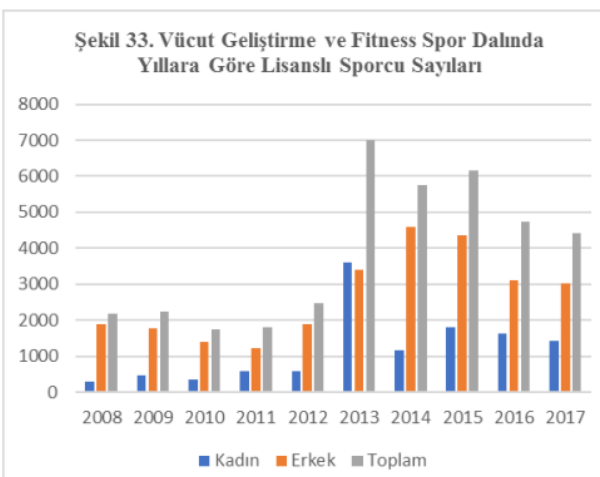

Vücut Geliştirme ve Fitness branșında 2007 yılına kadar 1664 kadın, 9486 erkek toplam $11150 \quad$ sporcu kayitlı görülmektedir. $\mathrm{Bu}$ branşta en yüksek toplam sporcu lisans1 sayisina 2013 
yılında ulaşılırken; en az sporcu lisansı 2010 yılında çıkarılmıştır. Sporcu lisansları en yüksek düzeye kadınlarda 2013 yllinda; erkeklerde ise 2014 yllinda gelmiştir.

Tablo 34: Wushu Spor Dalında Yıllara Göre Lisanslı Sporcu Sayıları

\begin{tabular}{cccc}
\hline \multicolumn{4}{c}{ LiSANSLI SPORCU SAYISI } \\
Yıllar & Kadın & Erkek & Toplam \\
\hline 2008 & 738 & 4109 & 4847 \\
2009 & 1089 & 5013 & 6102 \\
2010 & 1176 & 5070 & 6246 \\
2011 & 1368 & 6246 & 7614 \\
2012 & 1727 & 6829 & 8556 \\
2013 & 2221 & 8314 & 10535 \\
2014 & 2480 & 8350 & 10830 \\
2015 & 2885 & 8436 & 11321 \\
2016 & 3393 & 9097 & 12490 \\
2017 & 4933 & 11305 & 16238 \\
\hline
\end{tabular}

yüksek toplam sporcu lisansı sayısına 2017 yllında ulaşıllıken; en az sporcu lisans1 2008 yılında çıkarılmıştır. Sporcu lisansları en yüksek düzeye hem kadınlarda hem de erkeklerde 2017 yılında ulaşmıştır.

Tablo 35: Yüzme Spor Dalında Yıllara Göre Lisanslı Sporcu Sayıları

\begin{tabular}{cccc}
\hline \multicolumn{4}{c}{ LíSANSLI SPORCU SAYISI } \\
Yıllar & Kadın & Erkek & Toplam \\
\hline 2008 & 2259 & 3478 & 5737 \\
2009 & 1751 & 2701 & 4452 \\
2010 & 2470 & 3376 & 5846 \\
2011 & 3290 & 4754 & 8044 \\
2012 & 5646 & 8111 & 13757 \\
2013 & 7455 & 9040 & 16495 \\
2014 & 7044 & 8621 & 15665 \\
2015 & 8904 & 9142 & 18046 \\
2016 & 7131 & 7659 & 14790 \\
2017 & 7375 & 9506 & 16881 \\
\hline
\end{tabular}

Wushu branşında 2007 yılına kadar 963 kadın, 4160 erkek toplam 5123 sporcu kayıtlı görülmektedir. $\mathrm{Bu}$ branşta en
Yüzme branşında 2007 yllına kadar 17901 kadın, 29514 erkek toplam 47415 sporcu kayitlı görülmektedir. $\mathrm{Bu}$ branşta en yüksek toplam sporcu lisansı sayısına 
Ersöz, G., Alagöz, B. / Türkiye’de 2007-2017 Yılları Arasında Spor Branşları ve Cinsiyete Göre Sporcu Sayılarının Dağılımı

2015 yılında ulaşılırken; en az sporcu lisansı 2009 yılında çıkarılmıştır. Sporcu lisansları en yüksek düzeye kadınlarda 2015 y1lında; erkeklerde ise 2017 y1lında gelmiştir.

Tablo 36: Gelişmekte Olan Spor Dallarında Yıllara Göre Lisanslı Sporcu Sayıları

\begin{tabular}{cccc}
\hline \multicolumn{4}{c}{ LISANSLI SPORCU SAYISI } \\
Yıllar & Kadın & Erkek & Toplam \\
\hline 2008 & 21 & 22 & 43 \\
2009 & 153 & 376 & 529 \\
2010 & 253 & 456 & 709 \\
2011 & 391 & 708 & 1099 \\
2012 & 163 & 460 & 623 \\
2013 & 588 & 1898 & 2486 \\
2014 & 294 & 3041 & 3335 \\
2015 & 237 & 1579 & 1816 \\
2016 & 70 & 463 & 533 \\
2017 & 151 & 153 & 304 \\
\hline
\end{tabular}

Şekil 36. Gelişmekte Olan Spor Dallarında Yıllara Göre Lisanslı Sporcu Sayıları

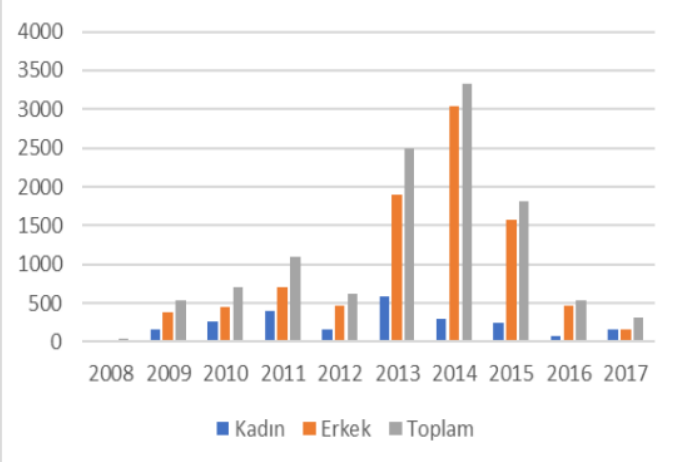

Gelişmekte Olan Spor Dallarında 2008 yılında ilk kez lisans çıkartılmaya başlanmıştır. 2008 yılında 21 kadın, 22 erkek toplam 43 sporcu kayıtlı görülmektedir. Bu branşta en yüksek toplam sporcu lisansı sayısına
2014 yılında ulaş1lırken; en az sporcu lisans1 2008 yılında çıkarılmıştır. Sporcu lisansları en yüksek düzeye kadınlarda 2013 yılında; erkeklerde ise 2014 yılında gelmiştir.

Tablo 37: Hokey Spor Dalında Y1llara Göre Lisanslı Sporcu Sayıları

\begin{tabular}{cccc}
\hline \multicolumn{4}{c}{ LISANSLI SPORCU SAYISI } \\
Yıllar & Kadın & Erkek & Toplam \\
\hline 2010 & 276 & 429 & 705 \\
2011 & 224 & 240 & 464 \\
2012 & 255 & 480 & 735 \\
2013 & 506 & 686 & 1192 \\
2014 & 313 & 698 & 1011 \\
2015 & 406 & 717 & 1123 \\
2016 & 122 & 217 & 339 \\
2017 & 647 & 820 & 1467 \\
\hline
\end{tabular}

Şekil 37. Hokey Spor Dalında Yıllara Göre Lisanslı Sporcu Sayları

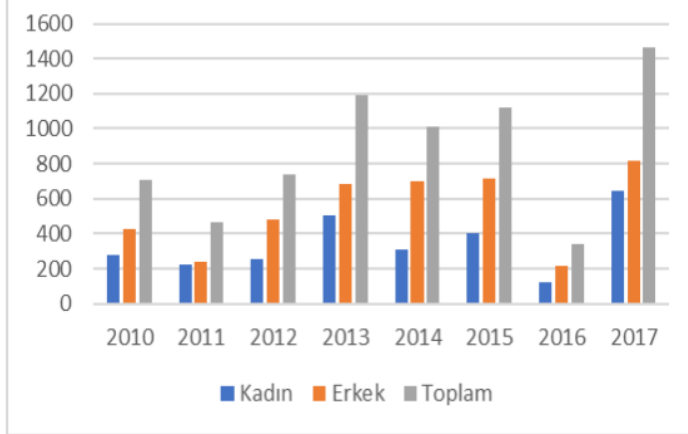

Hokey branşında 2009 yılından itibaren lisans kayıtları görülmektedir. 2009 yılında 1868 kadın, 3467 erkek toplam 5335 sporcu kayıtlı görülmektedir. $\mathrm{Bu}$ branşta en yüksek toplam sporcu lisansı 
sayısına 2017 yılında ulaşılırken; en az sporcu lisansı 2016 yılında çıkarılmıştır. Sporcu lisansları en yüksek düzeye hem kadınlarda hem de erkeklerde 2017 yılında ulaşmıştır.

Tablo 38: Özel Sporcular Spor Dalında Y1llara Göre Lisanslı Sporcu Sayıları

\begin{tabular}{cccc}
\hline \multicolumn{4}{c}{ LISANSLI SPORCU SAYISI } \\
Yıllar & Kadın & Erkek & Toplam \\
\hline 2010 & 354 & 721 & 1075 \\
2011 & 147 & 645 & 792 \\
2012 & 207 & 629 & 836 \\
2013 & 507 & 1307 & 1814 \\
2014 & 396 & 1095 & 1491 \\
2015 & 507 & 1011 & 1518 \\
2016 & 351 & 684 & 1035 \\
2017 & 292 & 770 & 1062 \\
\hline
\end{tabular}

Özel Sporcular branşında 2009 yılından itibaren lisans kayıtları görülmektedir. 2009 yılında 2091 kadın, 6884 erkek toplam 8975 sporcu kayıtlı görülmektedir.
$\mathrm{Bu}$ branşta en yüksek toplam sporcu lisansı sayısına 2013 yılında ulaşılırken; en az sporcu lisansı 2011 yılında çıkarılmıştır. Sporcu lisansları en yüksek düzeye hem kadınlarda hem de erkeklerde 2013 yılında ulaşmıştır.

Tablo 39: Kizak Spor Dalında Yillara Göre Lisanslı Sporcu Sayıları

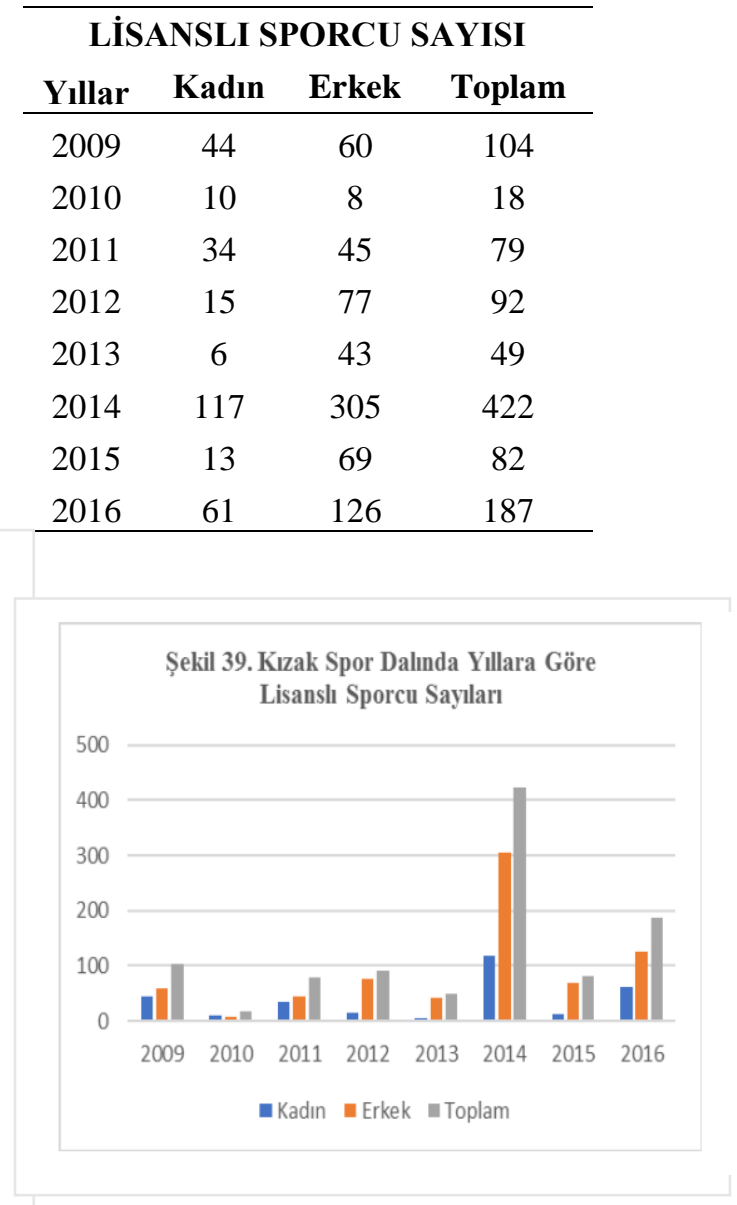

Kızak branşında 2009 yılından itibaren lisans kayıtları görülmektedir. 2009 yılında 40 kadın, 64 erkek toplam 104 sporcu kayıtlı görülmektedir. Bu branşta en yüksek toplam sporcu lisansı sayısına 
2014 y1lında ulaşılırken; en az sporcu lisansı 2010 yılında çıkarılmıştır. Sporcu lisansları en yüksek düzeye hem kadınlarda hem de erkeklerde 2014 yılında ulaşmıştır.

\section{TARTIŞMA ve SONUÇ}

Bu araştırma Türkiye' de GHGM' ne kayıtlı olan sporcuların spor branşlarına ve cinsiyete göre istatistiki bilgilerini ortaya koymak amaciyla yapılmıştır. Çalışmanın verileri spor branşlarında yıllara göre tutarlı olmayan artış ve azalmalar olduğunu ve kadın sporcu sayılarının erkeklere göre düşük düzeyde olduğunu ortaya koymuştur. Tüm spor branşlarında sporcu sayılarının yeterli düzeylere ulaşmadığı da ayrıca çalışmada görülmüştür.

Türkiye' de sporcu lisanslarının analizi ile ilgili alanyazına bakıldığında branşa göre istatistik analize daha önce rastlanmamıştır fakat toplam sporcu sayılarının Türkiye nüfusuna oranlamasına çeşitli çalışmalarda yer verilmiştir. Ersöz ve Arun (2019) tarafından yapılan bir araştırmada Ülkemizde erkek nüfusun \% 8' inin, kadın nüfusun $\%$ 4' ünün toplam nüfusun ise $\%$ 6'sının sporcu lisansına sahip olduğu görülmektedir. Lisansı daha çok çocukgenç ve yetişkin kesimin çıkardığı göz önünde bulundurularak 10-44 yaş grubunun nüfusuna sporcu lisanslarını oranladığımızda ise erkek nüfusun \% 14' ünün, kadın nüfusun $\% 8$ ' inin toplam nüfusun ise $\% 11^{\prime}$ inin sporcu lisansina sahip olduğu görülmüştür.

Türkiye'deki sporcu sayılarını ortaya koyan ve bu istatistiki bilgileri farklı ülkelerle karşılaştıran bir çalışmada da Türkiye'de genel olarak 115 kişiden birinin spor yaptığı buna rağmen, Almanya'da ve Lüksemburg'da her dört kişiden birinin spor yaptığını belirtmiş, birçok Avrupa Ülkesinde nüfusunun yarısına yakını spor yaparken, Türkiye'nin sadece binde altısının lisanslı spor yaptığını ileri sürmüştür (Karahüseyinoğlu ve ark., 2005).

$\mathrm{Bu}$ konuda başka bir araştırma raporunda 2006 y1linda 1.567 .708 toplam sporcu olduğu rapor edilmiş ve nüfus 73 milyon olarak varsayıldığında nüfusun \% 2.15 sporcu olduğu belirtilmiştir. 2019 y1lında ise bu oran toplam nüfusa göre \% 6; çocuk, genç ve yetişkin nüfusa göre (10-44 yaş aralığı) ise \% 11 olarak belirtilmiştir (Ersöz ve Arun, 2019).

Taşrada yer alan Gençlik Hizmetleri ve Spor İl Müdürlüklerinin il bazında başarıları, Spor Genel Müdürlüğü tarafından 2005 yılı itibarıyla lisanslı sporcu sayısı ile ilişkilendirildiği için, söz 
konusu lisanslı sporcu oranlarının gerçek oranlardan daha az olma ihtimali göz önünde bulundurulduğunda, sistemden alınan verilere göre yapılan analizin çok da altında bir lisanslı sporcu sayısına sahip olabileceğimiz söylenebilir.

Sonuç olarak Ülkemizde sporcu sayılarının yeterli düzeylerde olmaması, spor branşlarında yıllara göre sporcu sayılarında doğrusal artış şeklinde olmayan değişikliklerin görülmesi ve kadın sporcu sayılarının erkeklere göre çok düşük düzeylerde seyretmesi sporun gelişimi açısından sorunlu bir durumun varlığını göstermektedir. Türkiye' de sporun yönetilmesinde söz sahibi olan Gençlik ve Spor Bakanlığı, Spor Genel Müdürlüğü, Spor Federasyonları ve Türkiye Milli Olimpiyat Komitesi' nin işbirliği ile söz konusu sporcu sayısına yönelik sayısal verileri analiz edilmesi ve yıllara göre sporcu sayılarındaki artış ve azalmaların nedenlerinin araştırılması ülkemizde sporun gelişimi adına faydalı olacaktır. $\mathrm{Bu}$ araştırma neticesinde bir başka öneri ise Spor Genel Müdürlüğü bünyesinde spor bilimleri konusunda araştırmalar yapan, lisansüstü eğitime sahip araştırmacıların yer aldığı Ar-Ge merkezinin kurulması ve spor ve fiziksel aktivitenin ülkemizde geniş kitlelere yayılması için projeler üretmesinin sağlanmasıdır. Ülkemizde spor ve egzersiz ortamlarında mevcut durumun her yönüyle ortaya konulması ve gelecek için projeler geliştirilmesi, gerçek anlamda gelişimin sağlanması için gereklidir.

\section{KAYNAKÇA}

Erkiner, K. (2006). Ülke Sporcu Potansiyelinin Belirlenmesinde Yöntemler ve Yerel Yönetimler, Fiziksel Aktivite, Sağlıklı Yaşam ve Yerel Yönetimler Sempozyumu, 27-28 Nisan, Eskişehir.

Ersöz, G. ve Arun, K. (2019). Spor Genel Müdürlüğü Tarafından 2018 Yılına Kadar Kaydı Tutulan Sporcu Lisansı Sayılarının Kayılı Nüfus Bilgilerine Göre Analizi, 3.Uluslararası Sağlık Bilimleri Kongresi, 24-26 Ekim 2019, Çanakkale.

Karasar, N. (2003). Bilimsel araştırma yöntemi: Kavramlar, ilkeler, teknikler [Scientific research method: Concepts, principles, techniques]. Baskl. Ankara: Nobel.

Karahüseyinoğlu, M. F., Ramazanoğlu, F., Nacar, E., Ramazanoğlu, O., ve Altungül, O. (2005). Türkiyenin Spordaki Konumunun Baz1 Avrupa Ülkeleri İle Karş1laştırılması. Fırat Üniversitesi Doğu Araştırmaları Dergisi, 3(3), 75-82.

Smoll, F. L., ve Smith, R. E. (Eds.). (2002). Children and youth in sport: A biopsychosocial perspective. Kendall Hunt Publishing Company.

https://sgm.gsb.gov.tr/Sayfalar/175/105/Istatistikle

r Erişim Tarihi: 18 Eylül 2018 